\title{
Life in the Underworld: Anchialine cave biology in the era of speleogenomics
}

\author{
Jorge L. Pérez-Moreno ${ }^{1 *}$, Thomas M. Iliffe ${ }^{2}$, and Heather D. Bracken-Grissom ${ }^{1}$ \\ ${ }^{1}$ Department of Biological Sciences, Florida International University, Biscayne Bay Campus, North Miami FL 33181, USA \\ ${ }^{2}$ Department of Marine Biology, Texas A\&M University at Galveston, Galveston, TX 77553, USA
}

\begin{abstract}
Anchialine caves contain haline bodies of water with underground connections to the ocean and limited exposure to open air. Despite being found on islands and peninsular coastlines around the world, the isolation of anchialine systems has facilitated the evolution of high levels of endemism among their inhabitants. The unique characteristics of anchialine caves and of their predominantly crustacean biodiversity nominate them as particularly interesting study subjects for evolutionary biology. However, there is presently a distinct scarcity of modern molecular methods being employed in the study of anchialine cave ecosystems. The use of current and emerging molecular techniques, e.g., next-generation sequencing (NGS), bestows an exceptional opportunity to answer a variety of long-standing questions pertaining to the realms of speciation, biogeography, population genetics, and evolution, as well as the emergence of extraordinary morphological and physiological adaptations to these unique environments. The integration of NGS methodologies with traditional taxonomic and ecological methods will help elucidate the unique characteristics and evolutionary history of anchialine cave fauna, and thus the significance of their conservation in face of current and future anthropogenic threats. Here we review previous contributions to our understanding of anchialine biodiversity and evolution, and discuss the potential of "speleogenomic" methods for future research in these threatened systems.
\end{abstract}

Keywords: biospeleology, crustacea, evolution, genomics, phylogeography

Received 22 September 2015; Revised 12 April 2016; Accepted 13 April 2016

Citation: Pérez-Moreno J.L., Iliffe T.M., and Bracken-Grissom H.D., 2016. Life in the Underworld: Anchialine cave biology in the era of speleogenomics. International Journal of Speleology, 45 (2), 149-170. Tampa, FL (USA) ISSN 0392-6672

http://dx.doi.org/10.5038/1827-806X.45.2.1954

\section{INTRODUCTION}

The term anchialine, from the Greek "anchialos" meaning "near the sea", is generally used in reference to tidally-influenced subterranean estuaries within crevicular and cavernous karst and volcanic terrains that extend inland to the limit of seawater penetration' (Stock, 1986; Iliffe, 1992; Bishop et al., 2015). Despite tidal influences acting through small conduits and/or the porosity of the surrounding limestone or volcanic rock, anchialine systems have restricted biological connectivity with adjacent water bodies and their associated ecosystems (Iliffe \& Kornicker, 2009; Becking et al., 2011; Bishop et al., 2015). Anchialine caves are occasionally interconnected, forming extensive underground networks and giving rise to large and spatially complex habitats (e.g., cenotes in the Yucatan Peninsula, Mexico, Beddows et al., 2007; Mylroie \& Mylroie, 2011). Anchialine caves' stratified waters often further increase their habitat complexity
(Moritsch et al., 2014). This stratification involves a surface layer of meteoric freshwater, separated from underlying marine water by a halocline or mixing zone, where dissolved oxygen levels are low or absent and clouds of hydrogen sulfide occur (Fig. 1, Sket, 1996; Humphreys, 1999; Iliffe, 2000; Seymour et al., 2007; Becking et al., 2011; Gonzalez et al., 2011). Anchialine systems are widely distributed around the world, mostly isolated from each other, and occurring on karst or volcanic coastlines of islands and peninsulas. Partially explored locations include (but are not limited to) the islands of the Bahamas, Bermuda, Galapagos (Ecuador), Hawaii (U.S.A.), the Ryukyus Archipelago (Japan), Canary and Balearic Islands (Spain), the Philippines, Indonesia, Christmas Island and Barrow Island (Australia), and peninsular areas of the Yucatan (Mexico), Belize and Cape Range (Australia, Iliffe, 1991; Jaume et al., 2001; Humphreys, 2002; Pesce \& Iliffe, 2002; Fosshagen \& Iliffe, 2004; Kano \& Kase, 2004; Namiotko et al., 2004; Koenemann 


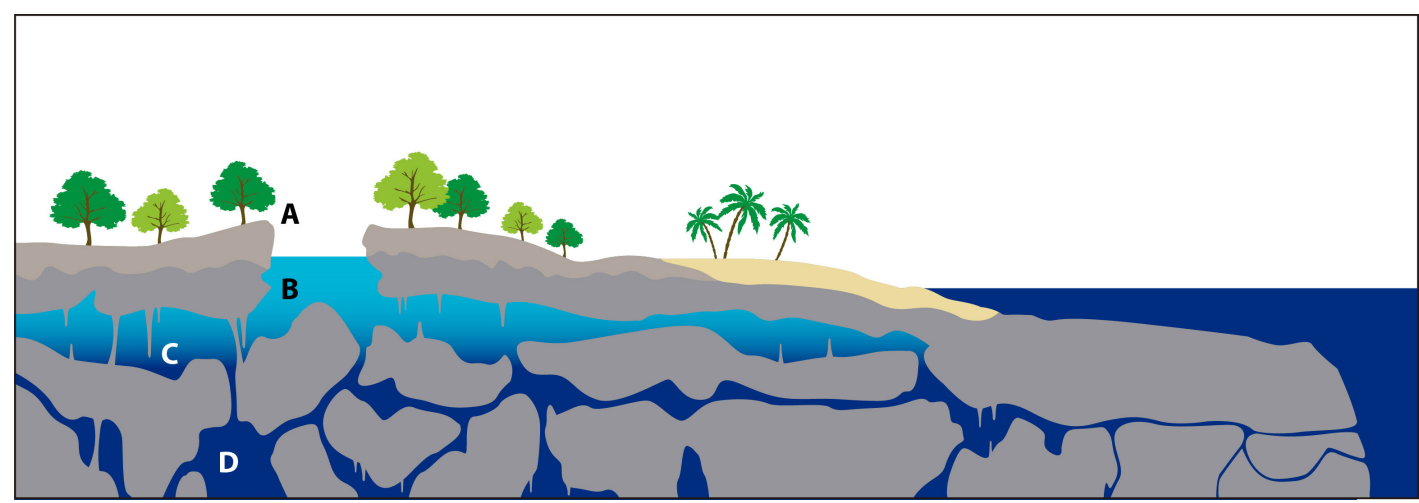

Fig. 1. Schematic representation of an anchialine cave system. A) "Blue hole", "Cenote" or "Sinkhole" opening to the surface; B) Meteoric freshwater lens upper stratum; C) Halocline or mixing zone - often accompanied by a layer of hydrogen sulfide by-product of microbial activity; D) Hypoxic saltwater lower stratum - devoid of sunlight, food webs in this habitats are likely to depend on chemosynthetic microbial communities. Diagram by J.M. Song-López.

et al., 2009a; Russ et al., 2010; Becking et al., 2011; Gonzalez et al., 2011). Anchialine habitats are locally known by a variety of names: the most notable being Australia's "sinkholes", Belize's and the Bahamas' "blue holes", and the Yucatan's "cenotes" (from the Maya word ts'onot, Jaume et al., 2001; Iliffe \& Kornicker, 2009; Humphreys et al., 2012). These habitats can take a variety of different forms including pools, lava tubes, faults in volcanic rock, karstic limestone cave systems, and connected groundwater (Fig. 2, Iliffe, 1992; Namiotko et al., 2004; Becking et al., 2011; Mylroie \& Mylroie, 2011), yet they all share the same characteristic patterns of stratification and limited biological connectivity with surrounding environments (Kano \& Kase, 2004; Hunter et al., 2007; Porter, 2007).

Anchialine caves have a relatively young history in their current state and locations (Mylroie \& Mylroie, 2011), originating when formerly dry caves were flooded by rising, post-glacial sea-levels in the early Holocene (11,650-7000 years ago, Becking et al., 2011; Smith et al., 2011). However, anchialine habitats have existed for millions of years (Iliffe, 2000; Suárez-Morales et al., 2004; Sathiamurthy \& Voris, 2006; Becking et al., 2011). Previous studies of cave geology have shown that a great number of extensive and complex caves were formed by the cyclical sea-level changes associated with the Quaternary period ( 2.5 million years ago to present, Mylroie \& Mylroie, 2011), while the fossil record indicates that the putative ancestors of modern anchialine fauna were already present in marine systems hundreds of million years ago (e.g., remipedes 328306 mya, atyid shrimp 145-99 mya, Brooks, 1955; Emerson, 1991; von Rintelen et al., 2012; Moritsch et al., 2014). It is therefore possible that the colonization of anchialine caves and similar marine crevicular habitats has been occurring since at least the late Jurassic (i.e., the thaumatocypridid ostracod Pokornyopsis feifeli Triebel, 1941,
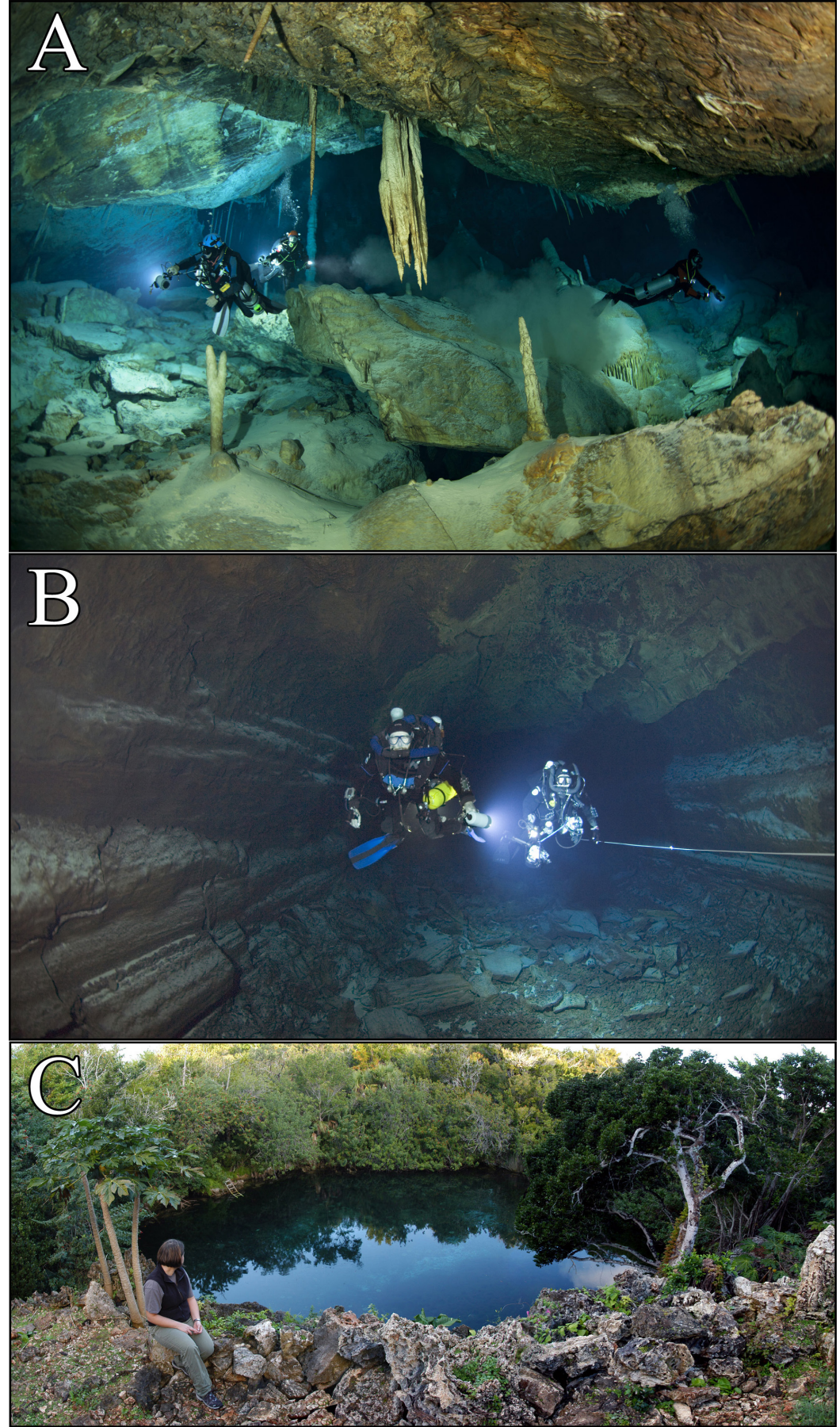

Fig. 2. Anchialine systems can be found in a range of different forms including (but not limited to): A) karst cave systems (Crystal Cave, Bermuda - photo by J. Heinerth);

B) lava tubes (Jameos del Agua, Lanzarote, Canary Islands, Spain - photo by J. Heinerth), and C) pools (Angel Pool, Bermuda - photo by T. Thomsen). 
Iglikowska \& Boxshall, 2013; Jaume et al., 2013). The particular geochemistry that distinguishes anchialine habitats (low dissolved oxygen, stratified and oligotrophic waters, Moore, 1999; Seymour et al., 2007; Pohlman, 2011; Neisch et al., 2012), coupled with the distributional patterns and isolation of these cave systems has allowed for a high proportion of endemism among their autochthonous fauna (Iliffe, 1993; Myers et al., 2000; Porter, 2007; Iliffe \& Kornicker, 2009). Due to these circumstances, novel and complex chemosynthetically based food webs have arisen, analogous to those found in the deep seas (Sarbu et al., 1996; Engel et al., 2004; Opsahl \& Chanton, 2006; Engel, 2007; Porter et al., 2009; Pohlman, 2011).

Recent improvements in scientific cave diving technology and techniques (e.g., mixed-gas rebreathers) have facilitated access and greatly contributed to sampling capabilities in anchialine cave systems (Iliffe $\&$ Bowen, 2001; Iliffe \& Kornicker, 2009; Iliffe, 2012). Increased access to these systems has resulted in the description of numerous species, genera, families, orders and even a new class (Remipedia) previously unknown to science (Yager, 1981; Iliffe, 2002). However, the scarcity of modern genomic methods being employed in the study of anchialine ecosystems remains to be addressed. Although biospeleological studies that incorporate genetic methodologies have been previously conducted (Adams \& Humphreys, 1993; Porter, 2007; Page et al., 2008; Juan et al., 2010), the use of modern sequencing technologies for the study of anchialine caves still lags behind their freshwater and terrestrial counterparts (e.g., Friedrich et al., 2011; Protas et al., 2011; Friedrich, 2013; Gross et al., 2013), with perhaps the exception of some localized studies of specific taxa (e.g., Meland \& Willassen, 2007; Russ et al., 2010; Neiber et al., 2012; von Reumont et al., 2014). In this contribution we examine the current state of knowledge on anchialine cave ecology, biodiversity, and evolution and also discuss the advantages and possibilities that biospeleological investigations at the genomic level, or "speleogenomics", will provide to the understanding of these fascinating systems - with special emphasis in the areas of biodiversity, phylogeography, and molecular evolution.

\section{ECOLOGY AND BIODIVERSITY OF ANCHIALINE CAVES}

Anchialine caves display unique species assemblages with biodiversity often varying not only by location, but also in response to abiotic factors such as tidal flux, salinity, temperature, dissolved oxygen, and water stratification (e.g., haloclines, Iliffe, 2002; Gonzalez et al., 2011). Cave food webs have been regarded as nutrient poor and dependent on external inputs of nutrients such as decaying organic matter (Dickson, 1975; Sket, 1996; Neisch et al., 2012), but recent discoveries have attributed considerable importance to the chemosynthetic activity of bacterial communities (Sarbu et al., 1996; Pohlman et al., 1997; Engel et al., 2004; Engel, 2007; Seymour et al., 2007; Gonzalez et al., 2011; Humphreys et al., 2012; Pakes et al., 2014; Pakes \& Mejía-Ortíz, 2014), particularly with increasing distances from cave openings (Neisch et al., 2012). In fact, productivity of cave chemoautotrophic communities appears to correlate with diversity of heterotrophic microbes and of macro-invertebrates in higher trophic levels, which suggests that microbial diversity plays a role in mediating cave biodiversity (Engel, 2007; Porter et al., 2009). Chemosynthetic ectosymbioses between bacteria and several invertebrate phyla have been documented in similar ecosystems (Dubilier et al., 2008; Goffredi, 2010), including freshwater caves (Dattagupta et al., 2009; Bauermeister et al., 2012). Recent studies suggest that analogous interactions occur in anchialine systems, with both ecto- and endosymbioses of chemoautotrophic bacteria having been found in two crustacean taxa (the remipede Xibalbanus tulumensis and the atyid shrimp Typhlatya pearsei) from anchialine caves (Pakes et al., 2014; Pakes \& Mejía-Ortiz, 2014). Other microbiota also present in anchialine caves include microscopic eukaryotes such as fungi, protozoa, and rotifers, but documentation on their biodiversity and ecological roles in anchialine caves is limited (Engel, 2007).

Assemblages of anchialine cave fauna display unique variations and stratified ecological niches, due to thermoclines and haloclines, among and within caves. An interesting phenomenon observed in these systems is the assemblage cave "types" (e.g., Remipedia or Procaridid communities) - where similar crustacean communities of only a few different genera are found inhabiting different caves, often geographically distant from each other, and displaying predictable generic compositions (Poore \& Humphreys, 1992; Jaume et al., 2001; Humphreys \& Danielopol, 2006; Neiber et al., 2011). Remipedetype caves typically contain remipedes and other crustacean stygobionts (aquatic and cave-dwelling) such as cirolanid isopods, hadziid amphipods, calanoid copepods, ostracods, thermosbaenaceans, and atyid shrimps; while Procaridid-type communities are characterized by the presence of shrimp from the genus Procaris Chace and Manning, 1972 along with a number of species of alpheid, atyid, and barbouriid shrimps (Chace \& Manning, 1972; Humphreys \& Danielopol, 2006; Neiber et al., 2011). The exact reasons underlying these phenomena of community "types" and disjunct distributions continue to be subject to investigation. The dominant hypothesis suggests that this community-type phenomenon is due to ancient geological patterns when many of these species and their ancestors originated (in the Tethys Sea during the Mesozoic), as these cave communitytypes tend to be associated with particular geographical features (e.g., Procaridid-type communities are more commonly located on sea-mount islands, Humphreys, 1999, 2002; Humphreys \& Danielopol, 2006; Neiber et al., 2011). The underlying mechanisms and processes that gave rise to cave biodiversity and its ecology constitute one of the major research themes for modern biospeleology (Peck \& Finston, 1993; Sket, 1999; Juan et al., 2010). 
Stygobitic fish, particularly eel-like fish (orders Ophidiiformes, Synbranchiformes) and eleotrids (order Perciformes), can be encountered in anchialine caves (Williams et al., 1989; Humphreys, 2001a; Medina-Gonzalez et al., 2001; Wilkens, 2001; Larson et al., 2013). However, these habitats are clearly dominated by invertebrates both in terms of diversity and biomass (Iliffe, 2002). Anchialine invertebrates encompass a diverse range of taxa, e.g., annelids, arachnids, chaetognaths, echinoderms, gastropods, poriferans, turbellarians, but most importantly crustaceans (Culver \& Sket, 2000; Engel, 2007; Mejía-Ortíz et al., 2007; Iliffe \& Kornicker, 2009; Solís-Marín \& Laguarda-Figueras, 2010; Bribiesca-Contreras et al., 2013). The reason for the high diversity of crustaceans, the endemism of higher taxa to anchialine systems, and their preponderance over other higher taxa is unknown (Stoch, 1995; Sket, 1999). The diversity, abundance, and widespread distributions of crustacean taxa in anchialine caves designate them as the ideal subjects for biospeleological, biogeographical, and evolutionary studies in these systems. The subphylum Crustacea is most commonly represented in anchialine cave environments by organisms from the following taxa:

\section{Order Decapoda (Class Malacostraca, Superorder Eucarida)}

Stygobitic decapods (Fig. 3A) are broadly distributed throughout tropical and subtropical anchialine caves (Bruce \& Davie, 2006; Hunter et al., 2007; Iliffe \& Kornicker, 2009). Freshwater crayfish, and both brachyuran and anomuran crabs (e.g., Munidopsis polymorpha Koelbel, 1892) have been found inhabiting cave environments (Iliffe, 1993; Ng et al., 1996; MejíaOrtíz et al., 2003; Cabezas et al., 2012; Álvarez et al., 2014), but the most common stygobitic decapods are the caridean shrimp (e.g., families Agostocarididae, Alpheidae, Atyidae, Barbouriidae, Hippolytidae, Palaemonidae, Chace \& Manning, 1972; Jaume \& Brehier, 2005; Hunter et al., 2007; Álvarez et al., 2012), procarididean (e.g., family Procarididae, Chace \& Manning, 1972; Felgenhauer et al., 1988; Bruce \& Davie, 2006; Bracken et al., 2010), stenopodidean (e.g., family Macromaxillocarididae, Álvarez et al., 2006), and gebiidean (e.g., family Laomediidae, Iliffe \& Kornicker, 2009) representatives living in anchialine systems around the world. Decapods are also among the most studied anchialine taxa, perhaps due to their charismatic nature and larger sizes (making them easier to be located and captured). However, the life-history, biogeography, and ecology of their anchialine cave inhabiting representatives for the most part remain poorly understood. Genetic studies of anchialine decapods have resulted in valuable insights on the phylogenetic position and biogeography of some species (for example Santos et al., 2006; Hunter et al., 2007; Page et al., 2008; Bracken et al., 2010; Botello et al., 2013), but investigations at the genomic or transcriptomic level remain scarce (Genomic Resources Development Consortium et al., 2014; Justice et al., 2015).

\section{Order Amphipoda (Class Malacostraca, Superorder Peracarida)}

Stygobitic amphipods (Fig. 3B) are small "shrimplike" crustaceans that can be found in a variety of cave environments, including freshwater and anchialine caves, and are distributed across the world with a considerable number of species described from the Atlantic region (Southern Europe, the Mediterranean, North America, and the Caribbean, Culver \& Pipan, 2009; Iliffe \& Kornicker, 2009). They are mostly represented in anchialine systems by a number of families from the suborder Senticaudata (e.g., Bogidiellidae, Hadziidae, Melitidae, Metacrangonyctidae Niphargidae, Salentinellidae, Jaume \& Christenson, 2001; Iliffe \& Kornicker, 2009; Gràcia \& Jaume, 2011). Recent molecular investigations have identified novel ectosymbioses between cave amphipods (Niphargus spp.) and sulphuroxidizing chemosynthetic bacteria (Dattagupta et al., 2009; Flot et al., 2010; Bauermeister et al., 2012). Although such findings concerned freshwater species, the findings raise the possibility of similar symbioses occurring in these environments.

\section{Order Isopoda (Class Malacostraca, Superorder Peracarida)}

Several families of isopods (e.g., Anthuridae, Asellidae, Atlantasellidae, Cirolanidae, Microcerberidae, Stenasellidae, Sphaeromatidae, Fig. 3C) are also found inhabiting cave systems, and their distributions tend to be relatively widespread. Isopods have been described from anchialine caves in Africa (Canary Islands), Asia (India, Indonesia, Japan, Malaysia), Europe (Mediterranean), North America (The Bahamas, Bermuda, Mexico and the Caribbean), Central and South America (Galapagos Islands), and Oceania (Australia and Polynesian Islands, Bruce \& Humphreys, 1993; Botoşăneanu \& Iliffe, 2006; Iliffe \& Botoşăneanu, 2006; Iliffe \& Kornicker, 2009). Cirolanids and sphaeromatid isopods are thought to have a marine origin, and are prevalent in anchialine systems, in contrast with other stygobitic families (e.g., Asellidae, Stenasellidae, Microcerberidae) that are likely to be product of colonizations from epigean freshwater habitats (Culver \& Pipan, 2009). A limited number of anchialine isopods have been included in genetic studies (for example, molecular phylogeny of Cirolanidae in Baratti et al., 2010), but none of these have been conducted in the context of anchialine systems, nor at the genomic/transcriptomic level.

\section{Orders Bochusacea and Thermosbaenacea (Class Malacostraca, Superorder Peracarida)}

Bochusaceans are small $(1.2-1.6 \mathrm{~mm})$ swimming peracarids that display several morphological regressive adaptations to cave life (lack of pigmentation and visual organs, Guțu \& Iliffe, 1998; Iliffe \& Kornicker, 2009). Only two species of Bochusacea are known, inhabiting anchialine and submarine caves from the Bahamas and Cayman Islands (Guț \& Iliffe, 1998). Two other species are also known to be found in deep-sea environments (Guțu \& Iliffe, 1998; Jaume et al., 2006). There is presently only 
a single bochusacean DNA sequence available online (small-subunit ribosomal RNA gene for Thetispelecaris remex), which resulted from a study that investigated peracarid monophyly (Spears et al., 2005). Thermosbaenaceans (Fig. 3D) are small $(<5 \mathrm{~mm})$ and enigmatic stygobitic swimming crustaceans. They tend to live in the water column in proximity to the halocline, where they feed off organic matter and microbial communities that inhabit these density interphases (Gràcia \& Jaume, 2011). They are globally distributed with some species found in Australia, Cambodia, the Mediterranean, and the Caribbean (Poore \& Humphreys, 1992; Iliffe $\&$ Kornicker, 2009). Although they are believed to have originated from marine ancestors, no extant epigean marine species have been found (Sket, 1996). Interestingly, thermosbaenaceans brood their young in a dorsal pouch, as opposed to a ventral marsupium as in the case of other extant peracarids (Olesen et al., 2015), and their brain's olfactory lobe seems to be less developed than in other blind cave-dwelling crustaceans (Stegner et al., 2015). Similarly to bochusaceans, genetic resources for the order Thermosbaenacea are severely lacking. Of the four thermosbaenacean DNA sequences deposited in Genbank (National Center for Biotechnology Information), only one is from an anchialine representative (Tethysbaena scabra). Furthermore, this sequence for the 18S rRNA gene from $T$. scabra was simply used as an outgroup for an asellote isopod phylogeny (Wägele et al., 2003). Despite recent innovations and examinations of thermosbaenacean morphology (Olesen et al., 2015; Stegner et al., 2015), genetic and genomic/ transcriptomic studies yet remain to be conducted.

\section{Orders Mictacea, Mysida, and Stygiomysida (Class Malacostraca, Superorder Peracarida)}

Mictaceans (Fig. 3E) are relatively small $(\sim 3 \mathrm{~mm})$ swimming peracarid crustaceans with only a single species in the order, Mictocaris halope (Bowman \& Iliffe, 1985). This single representative of the order inhabits anchialine caves of Bermuda, primarily in the deeper and harder to access areas (Bowman \& Iliffe, 1985). Stygobitic mysids (Fig. 3F) have a wide distribution with species endemic to anchialine caves in Africa, the Caribbean, Mediterranean, and India (Pesce \& Iliffe, 2002; Iliffe \& Kornicker, 2009). The Mysidacea has been split into two new orders, Mysida and Lophogastrida (Martin \& Davis, 2001; Spears et al., 2005 Porter et al., 2007), with stygobitic mysids belonging to the former. However, more recent molecular analyses have concluded that the order "Mysidacea" actually consists of three monophyletic groups and strongly suggest classifying some stygobitic mysids from the Caribbean and Mediterranean in the proposed order of "Stygiomysida" (Meland \& Willassen, 2007; Porter et al., 2007).

\section{Orders Cumacea and Tanaidacea (Class Malacostraca, Superorder Peracarida)}

Cumaceans (Fig. 3G) are peracarid crustaceans that can be found globally distributed with many

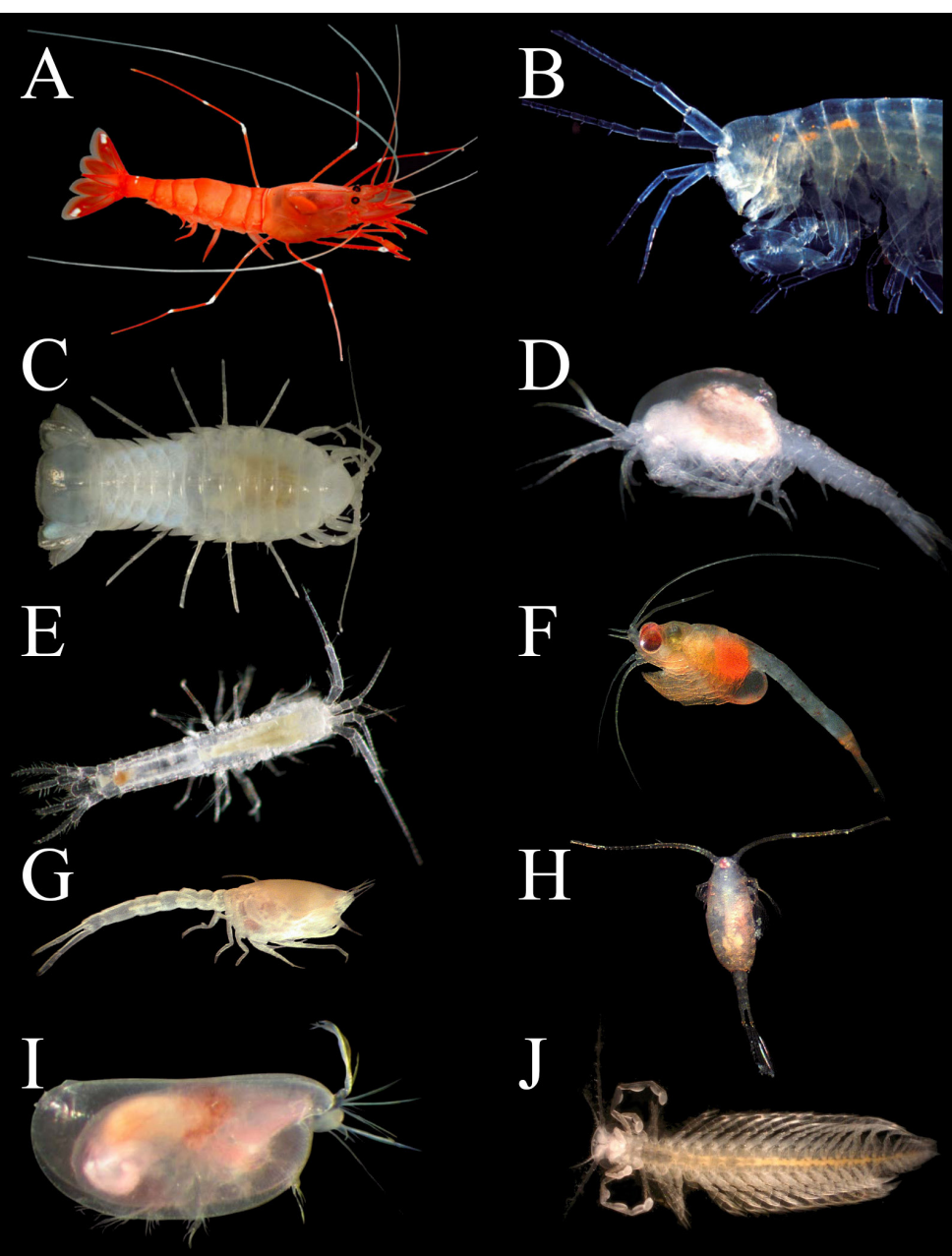

Fig. 3. Examples of various crustacean taxa found in anchialine caves: A) Parhippolyte sterreri (Decapoda); B) Pseudoniphargus grandimanus (Amphipoda); C) Bahalana caicosana (Isopoda); D) Tulumella sp. (Thermosbaenacea); E) Mictocaris halope (Mictacea); F) Bermudamysis speluncola (Mysida); G) Cumella abacoensis (Cumacea); H) Ridgewayia sp. (Calanoida); I) Spelaeoecia sp. (Ostracoda); J) Cryptocorynetes sp. (Remipedia) (Photographs of anchialine crustaceans by T. M. Iliffe).

species inhabiting areas as varied as the Australian Indo-Pacific to the Western Atlantic Ocean (Tafe \& Greenwood, 1996a, 1996b; Petrescu, 2003; Petrescu \& Iliffe, 2009). In the Western Atlantic region, cumaceans can be encountered both in oceanic basins (Petrescu et al., 1993; Petrescu, 1995) as well as in anchialine cave systems (Petrescu \& Iliffe, 1992, 2009). The physiology, life history, and ecology of most cumacean species are poorly understood (Gnewuch \& Croker, 1973; Corey, 1981; Duncan, 1984; Corbera et al., 2008;), especially when concerning that of stygobitic species. Tanaidaceans are another group of anchialine crustaceans found across the globe, with specimens having been recovered from caves in the Western Atlantic (the Bahamas Islands) and the tropical Indo-Pacific (Fiji Islands and Palau, Guțu \& Iliffe, 1989a; Guțu \& Iliffe, 1989b; Guțu \& Iliffe, 2011). They are small dorsoventrally flattened crustaceans with generally highly chitinized bodies, although some cave species with softer bodies have been found (Guțu \& Iliffe, 1989a; Guțu \& Iliffe, 1989b). Both cumaceans and tanaids are underrepresented in genetic studies in general (Shen et al., 2015), and especially in anchialine systems where these investigations are yet to be undertaken. 


\section{Suborder Nebaliacea (Class Malacostraca, Order Leptostraca) and Subclass Tantulocarida (Superclass Multicrustacea)}

Nebaliaceans are small shrimp-like benthic crustaceans typically from 5 to $15 \mathrm{~mm}$ long. Although they are mostly marine, an anchialine cave species of nebaliacean, known from the Turks and Caicos Islands, shares with its marine counterparts the ability to tolerate low-oxygen environments (Bowman et al., 1985; Walker-Smith \& Poore, 2001). There are no genetic resources available for anchialine Nebaliacea. Tantulocarids are small crustacean ectoparasites usually associated with other crustacean hosts (Boxshall \& Huys, 1989; Huys, 1990). Stygobitic tantulocarids have been described parasitizing harpacticoid copepods in anchialine caves of the Canary Islands (Boxshall \& Huys, 1989; Iliffe $\&$ Kornicker, 2009). Recent molecular phylogenetic investigations have suggested a close relation between tantulocarids and the subclass Thecostraca, and that Tantulocarida might in fact belong within this subclass as a sister group to Cirripedia (barnacles, Petrunina et al., 2014). However, the precise phylogenetic position of Tantulocarida still awaits further investigation (Petrunina et al., 2014).

\section{Orders Calanoida, Cyclopoida, Harpacticoida, Misophrioida, Platycopioida (Superclass Multicrustacea, Subclass Copepoda)}

Copepods (Fig. 3H) are amongst the most abundant and widely distributed taxa of aquatic animals, and exist in a wide range of environments across the globe (Boxshall \& Defaye, 2008). Not surprisingly, several orders from the subclass Copepoda can be found inhabiting most anchialine caves (Rouch, 1994; Gràcia $\&$ Jaume, 2011). They are typically encountered in the water column where they filter feed, except for a number of benthic bio-film grazers (e.g., cyclopoids $\&$ harpacticoids), and predatorial (e.g., cyclopoids $\&$ epacteriscids) species (Rouch, 1994; Fosshagen et al., 2001; Suárez-Morales et al., 2004, 2006; Suárez-Morales \& Iliffe, 2005a, 2005b, 2007; Iliffe \& Kornicker, 2009). Stygobitic copepods often present troglomorphies such as the reduction or absence of eyes and enlargement of eggs (Rouch, 1968). Genetic studies of copepods from anchialine caves are rare, with only a few studies having sequenced them for molecular phylogenetic purposes (Huys et al., 2006; Figueroa, 2011).

\section{Orders Halocyprida, Myodocopida, Platycopida, Podocopida (Class Ostracoda)}

Ostracods (Fig. 3I) are a very diverse and abundant group, with approximately 980 species described from caves and other subterranean habitats (Martens, 2004; Iliffe \& Kornicker, 2009; Hobbs, 2012). These small $(\sim 1 \mathrm{~mm})$ bivalved crustaceans are active swimmers and as such are commonly found in the water column, which may be a contributing factor to their long dispersal abilities (Humphreys \& Danielopol, 2006; Kornicker et al., 2009). Ostracods are distributed across anchialine habitats in both hemispheres, with some genera (e.g., Humphreysella) having representatives on opposite sides of the planet (Humphreys \& Danielopol, 2006; Kornicker et al., 2008, 2009; Iglikowska \& Boxshall, 2013). Stygobitic ostracods are easily distinguishable from epigean representatives by the morphological differences associated with their adaptations to cave life (i.e., smaller size, lack of eyes and pigmentation, Danielopol, 1981). Even though anchialine ostracods have not received much attention from molecular biologists, genetic and genomic/transcriptomic studies of ostracods in other environments have been conducted with great success (Oakley \& Cunningham, 2002; Oakley, 2005; Oakley et al., 2013). These studies provide a great basis on which to build upon future investigations of anchialine cave ostracods, which are likely to yield interesting evolutionary insights.

\section{Order Nectiopoda (Class Remipedia)}

Remipedes (Fig. 3J) are an unusual class of blind crustaceans with extensive body segmentation and lateral biramous swimming appendages that superficially resemble polychaete worms. Characteristics such as their cephalic anatomy warranted their classification in the subphylum Crustacea (Yager, 1981), which was later confirmed by molecular studies (von Reumont et al., 2012). Remipedes follow similar distribution patterns to those of halocyprid ostracods (Kornicker et al., 2007), and can be found exclusively in anchialine caves throughout the globe in a seemingly disjunct range of locations such as the Western Atlantic and Caribbean (Bahamas, Belize, Cuba, Dominican Republic, Yucatan), Africa (Canary Islands), and Western Australia (Sket, 1996; Yager \& Humphreys, 1996; Koenemann et al., 2003, 2004, 2007a, 2007c, 2009a; Lorentzen et al., 2007; Daenekas et al., 2009; Neiber et al., 2011, 2012; Hoenemann et al., 2013; Koenemann \& Iliffe, 2013). Although at first sight remipedes may appear morphologically primitive (Yager, 1994), they possess an advanced nervous system (Stemme et al., 2013), highly specialized feeding mouthparts for capturing prey (von Reumont et al., 2014), and they are the top predatory crustaceans in the low-oxygen anchialine systems they inhabit (Koenemann et al., 2007c; Iliffe \& Kornicker, 2009). Remipede larvae are so far only known from a single species in one cave (Koenemann et al., 2007b; 2009b; Olesen et al., 2014). Recent investigations of the remipede Xibalbanus tulumensis (Yager, 1987) have found that in addition to feeding from particulate matter in the water column, this species harbors chemosynthetic bacteria in ectosymbiosis that allow for the uptake of inorganic carbon as a supplement to their diet (Pakes \& Mejia-Ortíz, 2014). Furthermore, $X$. tulumensis has been shown to employ venom to capture and digest atyid shrimp, which makes it the first venomous crustacean ever documented (von Reumont et al., 2014).

\section{CURRENT ADVANCES AND FUTURE PROSPECTS}

Despite difficulties and dangers of sampling in anchialine caves (Iliffe \& Bowen, 2001; Iliffe, 2002, 
2012), previous studies have made monumental contributions to the field and an extraordinary amount of novel diversity from these habitats has been described to present day. Although traditional sanger DNA sequencing technologies (Glossary Box 1) have provided valuable insights to biospeleology (including but not limited to species identification, phylogenetics, and estimates of genetic diversity, Juan et al., 2010), high-resolution molecular data from cave systems have the potential to greatly expand the depth and breadth of knowledge to be gained from these types of studies. "Next-generation" DNA sequencing technologies (NGS), which allow for the sequencing of thousands of loci and/or hundreds of samples at a time, have scarcely been used by biospeleologists (Juan et al., 2010; Friedrich et al., 2011; Friedrich, 2013; Tierney et al., 2015). Previous biospeleological studies that incorporate genetic data to their investigation efforts have mainly focused on a single locus (for examples see: phylogeography Caccone \& Sbordoni, 2001; Buhay \& Crandall, 2005; population genetics - Russ et al., 2010; phylogenetics - Neiber et al., 2011, 2012) or a limited number of loci at a time (for examples see: phylogeography - Villacorta et al., 2008; Trontelj et al., 2009; Zakšek et al., 2009; phylogenetics - Leys et al., 2003; Hunter et al., 2007; Lefébure et al., 2007; Zakšek et al., 2007; Page et al., 2008; von Rintelen et al., 2012; Hoenemann et al., 2013), with only a small portion of those studies employing four or more loci in their analyses (for examples see: phylogenetics - Bracken et al., 2010; Botello et al., 2013; population genetics - Adams \& Humphreys, 1993). Employing a limited number of loci is suitable for the specific purposes that have been addressed so far, nevertheless the continuous development and improvement of molecular techniques offers an enormous potential for answering long-standing questions in biospeleology (Juan et al., 2010). These technologies open the way for analyses of a much higher resolution at an accelerated pace, and facilitate work on whole genomes and transcriptomes (Shendure \& Ji, 2008; Metzker, 2010; Lemmon et al., 2012; Friedrich, 2013). Additionally, NGS has the ability to provide researchers with vast amounts of data in a cost-effective manner (Metzker, 2010). NGS has also permitted the development of techniques that target many loci and/or many samples at once (Lemmon et al., 2012), such as "Targeted Sequencing" (Glossary Box 1, Meyer et al., 2007; Mamanova et al., 2010; Bybee et al., 2011a; Ekblom \& Galindo, 2011; Hedges et al., 2011; Cronn et al., 2012; Grover et al., 2012; Hancock-Hanser et al., 2013; Stull et al., 2013), "Anchored Hybrid Enrichment" (Glossary Box 1, Lemmon et al., 2012), and other high-throughput methods (Binladen et al., 2007; Miller et al., 2007; Lemmon \& Lemmon, 2012; Rohland \& Reich, 2012; Peñalba et al., 2014). These methods, some of which have already been employed successfully for pancrustacean phylogenetics (Bybee et al., 2011b), are easily adaptable for other purposes where massively parallel sequencing would be advantageous (e.g., multi-locus phylogenetics, metagenomics, DNA barcoding, biodiversity assessments, etc., Glossary Box 1). In combination with non-destructive tissue sampling techniques, the high-throughput nature of NGS paves the way for studies with large sample sizes with a minimal impact on natural populations. Minimizing the impact of sampling is of particular importance when working with rare and endemic cave species, especially those with small population sizes such as many anchialine cave dwellers. These methodologies can be employed for biological research in caves and similar environments to answer questions in a diverse array of areas such as biogeography/ phylogeography (Porter, 2007; Juan et al., 2010; Lemmon \& Lemmon, 2012; McCormack et al., 2013), ecology (Mock \& Kirkham, 2012), phylogenetics/ phylogenomics (Bybee et al., 2011b; Lemmon \& Lemmon, 2012; McCormack et al., 2013), cryptic speciation and evolution (Juan et al., 2010). The potential of next-generation sequencing has so far been demonstrated by the relatively few biospeleological studies that have successfully incorporated these modern techniques (e.g., Humphreys et al., 2012; Gross et al., 2013; O'Quin et al., 2013; von Reumont et al., 2012, 2014).

\footnotetext{
Sanger DNA Sequencing: A methodology for sequencing DNA molecules based on in-vitro replication with the incorporation of labeled chain-terminating dideoxynucleotides. Sanger sequencing allows for the sequencing of longer DNA reads (typically up to $\sim 1000$ contiguous bases) in a single reaction. Despite its limitations of one sequence per reaction, it is still useful for smaller-scale applications. Its relatively longer reads are also of utility for the validation of Next-generation sequencing data.

Next-generation DNA Sequencing (NGS): A term used to describe a variety of modern high-throughput DNA sequencing technologies, including but not limited to: the Illumina platform, Roche 454 pyrosequencing, Ion Torrent, Pacific Biosciences. They are more cost-effective than Sanger DNA sequencing (in terms of number of base pairs sequenced per monetary unit), and in recent years their use has demonstrated their enormous potential for studies at the genomic and transcriptomic scales.

Targeted/Directed Sequencing: Refers to a type of sequencing where only a specific region of interest (i.e., partial gene fragment) in the genome is sequenced for a particular application. It can be used in conjunction with next-generation sequencing technologies for cost-effectiveness, which also allows for projects of a much larger scale than with Sanger DNA sequencing technologies.

Metagenomics: It refers to the sequencing and study of genes across whole communities in an environmental sample. It is especially useful as it allows for the examination of microbes that are typically uncultured in laboratory settings.

DNA Barcoding: The use of a given genetic sequence as an identifying marker or "barcode" for a given species. The best loci to use for this purpose may vary among taxa, however most recent efforts have focused on the mitochondrial cytochrome c oxidase subunit I or COI (animals and most eukaryotes), the nuclear ribosomal internal transcribed spacer or ITS (fungi), and the chloroplast rbcL and matK genes (plants).
}

Glossary Box 1. 


\section{Cave biodiversity in the molecular era}

Current molecular tools, such as DNA barcoding, allow us to identify species by using a DNA sequence in a specific genomic region as an identifier or "barcode" (Savolainen et al., 2005; Shokralla et al.; 2014). DNA barcoding can be useful to discern species complexes that would otherwise go unnoticed due to morphological similarities or dissimilarities within a single species at different life-stages (Puillandre et al., 2011; Bracken-Grissom et al., 2012; Neiber et al., 2012). This is of special importance in anchialine caves and other subterranean systems where the possibility that troglomorphy and convergent evolution of morphological traits obscure phylogenetic relationships is significant (Wiens et al., 2003; Wilcox et al., 2004; Buhay \& Crandall, 2005; Porter, 2007; Trontelj et al., 2009). For example, Zakšek et al. (2009) investigated the seemingly widespread distribution of a common species of freshwater cave shrimp from the Balkan Peninsula (Troglocaris anophthalmus) and concluded that they should be considered distinct evolutionary significant units for conservation purposes. The study thus provides an example of how molecular tools can contribute to the delimitation of species with extensive convergent morphologies, which in turn could have important conservation implications. Molecular tools, such as DNA sequencing, will undoubtedly continue to be of importance for resolving cryptic species complexes that are pervasive in cave environments (Lefébure et al., 2007; Trontelj et al., 2009; Neiber et al., 2012). Similarly, morphological differences between lifestages within a species are commonplace among crustaceans, and in many instances pose important challenges for organism identification and taxonomic classification. This is especially common in poorly studied or rare species, where adult-larval linkages have not been determined experimentally due to logistical difficulties in obtaining samples or difficulty of larval rearing. DNA barcoding has proven useful to link morphologically distinct adults and larvae of the same species. For example, Bracken-Grissom et al. (2012) employed DNA barcoding regions and molecular systematics to show that the mid-water species Cerataspis monstrosa was in fact the larval stage of the deep-sea shrimp Plesiopenaeus armatus. The high-throughput capabilities of NGS can substantially benefit DNA barcoding efforts by targeting specific amplicons over hundreds of samples at a time (Glossary Box 2, Floyd et al., 2002; Wu et al., 2009;
Puillandre et al., 2011; Shokralla et al., 2014), making the sequencing and processing of numerous samples more efficient and cost-effective than with traditional Sanger DNA sequencing. These high-throughput capabilities can be especially useful for applications such as species identification, creation of species inventories (and large scale projects, such as the Barcode of Life initiative), detection of cryptic species complexes, and species delimitation (Savolainen et al., 2005; Bickford et al., 2007; Hajibabaei et al., 2007; Ratnasingham \& Hebert, 2007; Trontelj et al., 2009; Niemiller et al., 2013; Shokralla et al., 2014), all of which would be of benefit to research in anchialine caves (i.e., Bribiesca-Contreras et al., 2013).

\section{Phylogeography of anchialine cave ecosystems}

The vast amounts of genomic data that are possible to obtain with current technologies can be used to investigate evolutionary rates, diversification, and speciation among anchialine cave fauna, as well as enabling the investigation of population structure and gene-flow patterns at an unprecedented resolution (Leys et al., 2003; Porter, 2007; McCormack et al., 2013). Furthermore, these kinds of molecular data can be used to answer questions regarding the intriguing distribution patterns of cave fauna, such as the determination of species origins aligning with the climatic-relic or adaptive-shift hypotheses (Leys et al., 2003). In biogeographical terms, anchialine fauna have provided a very interesting source of debate, where several models have been proposed to explain their origins (Suárez-Morales \& Iliffe, 2005a; Porter, 2007; Culver et al., 2009; Iliffe \& Kornicker, 2009). The vicariance hypothesis states that the distribution of present-day anchialine fauna can be explained by plate tectonics, whereas the dispersal models suggest that stygobitic species dispersed to their present location when non-cave sister species invaded and adapted to cave environments (Jaume et al., 2001; Iliffe \& Kornicker, 2009). The actual mechanisms that gave rise to contemporary anchialine fauna are likely to be a more complex combination of the previously mentioned models (Culver et al., 2009). Molecular studies provide the opportunity to test these hypotheses (Page et al., 2008; Juan et al., 2010). A number of comparative phylogeography studies have already been undertaken to explain the evolutionary origins and distributional patterns of cave fauna (Caccone $\&$ Sbordoni, 2001; Espinasa \& Borowsky, 2001; Hunter et al., 2007; Ribera et al., 2010; von Rintelen et al.,

High-throughput sequencing: Refers to sequencing technologies that are able to generate vast amounts of data in a timely and cost-effective manner.

$m t D N A$ : Mitochondrial DNA is the DNA contained within the mitochondria organelles in eukaryotic organisms. mtDNA is derived from bacterial genomes early in eukaryotic evolution, and thus has different evolutionary origins than nuclear DNA. In most organisms it is exclusively maternally inherited.

Haplotypes: Refers to a set of genetic variations in a DNA sequence that share common inheritance. The scale of these variations and determination of haplotypes can be from Single Nucleotide Polymorphisms (SNPs) in a particular locus to groups of alleles on the same chromosome that are inherited together.

RNA-Seq: The term refers to the high-throughput sequencing of RNA from a specific tissue or organism at a discrete point in time. This provides the research with a snapshot of what is occurring in terms of transcription in that precise moment. Transcriptomic data can be used for studies in a wide range of areas such as evolution, development, physiology, adaptations to changing environments, and responses to physicochemical challenges.

Glossary Box 2. 
2012). Although in the case of most taxa, the evidence of their origins remains inconclusive at best (Phillips et al., 2013), the incorporation of modern molecular techniques with datasets at the genomic scale will undoubtedly shape the future of this research area [e.g., with use of phylogenomic approaches (Leaché et al., 2014)].

One method that can be applied to fine-scale questions of phylogeography (i.e., population to species) is Restriction-site associated DNA sequencing (i.e., RAD-Seq, Glossary Box 2). This is a methodology that allows for the sequencing, identification, and use of thousands of genetic markers, such as Single Nucleotide Polymorphisms (SNPs), distributed across hundreds of loci (Ekblom \& Galindo, 2011; McCormack et al., 2012, 2013). Restriction-site associated DNA sequencing reduces the complexity of the genome to be investigated with the use of restriction enzymes, which allows for genome-wide analyses to be performed without the computational and financial requirements of working with whole genomes (Davey \& Blaxter, 2010; Davey et al., 2011; Toonen et al., 2013). RAD-Seq provides high-resolution data that enable the identification of potentially thousands of these genetic markers across individuals and populations that can be employed for further analyses (Davey \& Blaxter, 2010; Peterson et al., 2012). For example, Coghill et al. (2014) used RAD-Seq to trace the colonization of caves by the blind Mexican cavefish Astyanax mexicanus. This methodology enabled them to find over 2,000 SNPs across the examined populations and provided evidence for at least four independent colonization events from surface populations to the caves, which suggests parallel evolution of the cave phenotypes observed in these stygobitic fish.

Cave-inhabiting organisms can be used as a proxy for investigating the connectivity of intricate cave systems, by looking at patterns of gene flow and population connectivity. Many submerged cave systems form underground web-like tunnels that extend for several hundreds of kilometers (e.g., the Yucatan cave systems, Iliffe, 2000; Beddows et al., 2007; Mylroie \& Mylroie, 2011; Moritsch et al., 2014). The complexity of these cave systems makes them extremely challenging to be explored using traditional cave-diving methods, mainly due to technological and physiological constraints. Several studies have used stygobiont genetics to assess present or historical hydrological connectivity of cave systems (e.g., Culver et al., 1995; Verovnik et al., 2004; Krejca, 2005). Culver et al (1995), while examining cave-adapted populations of Gammarus minus in West Virginia (USA), found congruent patterns between genetic differentiation and hydrology even when accounting for the possible selective pressures of different habitats. Krejca (2005) compared mitochondrial DNA phylogenies of two lineages of aquatic isopods (Cirolanidae and Asellidae) to examine the evolution of aquifers in Texas (USA) and northern Mexico. Despite finding differences between the two species examined, which could be explained by their individual ecologies and lifehistories, Krejca (2005) found congruency between the crustacean phylogenies and the hydrogeological history of the examined systems. The molecular examination of these two cave-dwelling isopod species allowed her to test a priori biogeographical hypotheses and investigate the evolution of the aquifers studied (Krejca, 2005). Further, Verovnik et al. (2004) also used molecular data (mtDNA, Glossary Box 2) of a crustacean species (Asellus aquaticus), in combination with paleogeographical information, to reveal possible scenarios of hydrological history of the Dinaric karst in the Balkan Peninsula. A study in the Pilbara region of Western Australia uncovered similar patterns amongst subterranean amphipods (Finston et al., 2007), where the mitochondrial haplotypes (Glossary Box 2) found were congruent with the hydrology of the tributaries examined as previously hypothesized (Humphreys, 2001b). Anchialine cave system hydrology can be similar to that of freshwater karstic cave systems, with the added complexity of underground connections to marine waters. Santos (2006) investigated the population genetics and connectivity patterns of the iconic Hawaiian anchialine shrimp Halocaridina rubra. Amongst his findings, he determined that there appears to be strong population subdivisions and a clear genetic structure particularly when surface distances between anchialine pools exceeded $30 \mathrm{~km}$. Santos' (2006) results also suggest that dispersal through subterranean conduits between anchialine pools is of more importance for this species than oceanic dispersal. These results contrast with Kano and Kase's (2004) findings of extensive oceanic dispersal by anchialine gastropods, further illustrating the importance of meticulous consideration of study species for cave connectivity purposes - where the chosen species' dispersal abilities should correspond to the geographical scales under investigation. Coupled with NGS technologies, these could offer a compelling alternative for the investigation of cave connectivity, by using population genomics as a proxy via methodologies such as RAD-Seq. Reducedrepresentation genome sequencing methodologies offer an unprecedented resolution (even compared to microsatellites) to genotype populations of cave organisms by sampling thousands of genomic regions at a time (Bradbury et al., 2015). The population structure and gene-flow patterns of those stygobiont populations could then be employed for a fine-scale evaluation of the connectivity of the anchialine caves under investigation, and complement traditional exploration efforts (e.g., scientific cave diving, Iliffe \& Bowen, 2001; dye-tracing, Beddows \& Hendrickson, 2008) of these spatially complex habitats.

\section{Evolution of troglomorphy}

RNA sequencing (RNA-Seq, Glossary Box 2) can provide invaluable resources for evolutionary studies of cave biota. The term RNA-Seq refers to the highthroughput sequencing of RNA from a specific tissue or organism at a discrete point in time (Wang et al., 2009; De Wit et al., 2012). This is achieved by reverse transcribing extracted RNA to cDNA, followed by highthroughput sequencing by an NGS platform (e.g, 454 pyrosequencing, Illumina, PacBio), and subsequent 
de novo assembly of the sequenced reads or the alignment of these reads to reference genomes (Wang et al., 2009; Deyholos, 2010; Martin \& Wang, 2011; Zhang et al., 2011; De Wit et al., 2012). The resulting transcriptome assembly can then be characterized to identify the transcripts that are being expressed in that tissue, organism, and/or life-stage (Ekblom \& Galindo, 2011; De Wit et al., 2012). Albeit being purely descriptive, a characterized transcriptome provides a base on which to build further analyses. The characterized transcriptome assembly can be used as a reference and both the original and additional sequenced reads (for other treatments, for example) can be mapped back to the assembly to obtain quantitative data of gene expression and genetic variation (Ellegren, 2008; Deyholos, 2010; Ekblom \& Galindo, 2011). These data can be further utilized for a variety of applications such as the development of molecular markers and even the identification of events associated with speciation processes (i.e., alternative splicing, Harr \& Turner, 2010; Ekblom \& Galindo, 2011). The small size of RNA sequence datasets, in comparison with whole-genome data, can also be valuable for the identification of new molecular markers and of novel proteins from non-model organisms in a computationally efficient manner. Additionally, transcriptomic data can be used for studies in a wide range of areas such as evolution (Harr \& Turner, 2010; Friedrich et al., 2011; Rehm et al., 2011; Wong et al., 2015), development (Zeng et al., 2011; Ichihashi et al., 2014), physiology (Dassanayake et al., 2009; Harms et al., 2013; Groh et al., 2014), adaptations to changing environments (Deyholos, 2010; Friedrich, 2013; Harms et al., 2013), and responses to physicochemical challenges (e.g., biomonitoring \& ecotoxicogenomics, Watanabe et al., 2008; Suárez-Ulloa et al., 2013a, 2013b).

RNA-Seq (Wang et al., 2009) can also be used to address more basic questions of cave evolution, by investigating the "speleotranscriptome" the transcriptomic profile of stygobitic fauna's physiological and morphological adaptations (Gross et al., 2013). In addition, such investigations can set the stage for addressing broader questions regarding natural selection and the evolution of phenotypic diversity, novel molecular functions, and complex organismal features (Christin et al., 2010). Animals inhabiting cave environments usually undergo various distinct physiological, morphological, and behavioral changes, which together are commonly referred to as "troglomorphy" (Desutter-Grandcolas, 1997; Porter \& Crandall, 2003; Mejia-Ortíz et al., 2006). Troglomorphic modifications can be classified in either progressive (constructive) or regressive (reductive) adaptations (Porter \& Crandall, 2003; Mejía-Ortíz \& Hartnoll, 2006; Mejía-Ortíz et al., 2006). In anchialine cave environments, stygobitic (aquatic and cavelimited) fauna typically present a combination of both types of troglomorphism. Examples of progressive adaptations may include cases such as those of enlarged sensory and ambulatory appendages, increased numbers of chemoreceptor setae, or enhancement of spatial orientation capabilities (Turk et al., 1996; Li \& Cooper, 2001, 2002; Mejía-Ortíz \& Hartnoll, 2006;). Regressive modifications involve the decrease or loss of features present in their epigean (surface) counterparts, e.g., reduced pigmentation, reduction or loss of visual functions, or decreased metabolism (Sket, 1985; Wilkens, 1986; Mejía-Ortíz \& López-Mejía, 2005; Mejía-Ortíz et al., 2006; Bishop $\&$ Iliffe, 2012). Troglomorphy is a perfect example of convergent morphological evolution where analogous traits have evolved in different lineages to adapt to similar environments (Caccone \& Sbordoni, 2001; Wilcox et al., 2004; Protas et al., 2007; Bishop \& Iliffe, 2012; Mejía-Ortíz et al., 2013). Species from a variety of crustacean taxa have been documented to have convergent characters (e.g., pigmentation, Beatty, 1949; Anders, 1956; body-size, Hobbs et al., 1977) by seemingly analogous mechanisms as adaptations to their subterranean life. This phenomenon poses the question on whether the underlying mechanisms of troglomorphy in cave crustaceans are also convergent at the molecular level. Although morphological and physiological convergence is well documented (Arendt \& Reznick, 2008), particularly in the case of adaptations to extreme environments (including caves, Wiens et al., 2003; Wilcox et al., 2004; Protas et al., 2006, 2007; Dassanayake et al., 2009), cases of convergent molecular evolution remain elusive (Tierney et al., 2015). Nevertheless, it has been suggested that this seemingly rare occurrence may be simply a product of the low-resolution genetic sampling that has been prevalent in the last few decades (Castoe et al., 2010). Recent investigations at the genomic and transcriptomic levels have indeed revealed evidence of convergent molecular evolution associated to phenotypic convergence (see Foote et al. (2015) for genomic convergence in marine mammals, Pankey et al. (2014) for transcriptomic convergence in bioluminescent squid, and Tierney et al. (2015) for transcriptomic convergence in subterranean beetles). A combination of transcriptomic and genomic approaches can help elucidate the strategies and mechanisms of adaptation to extreme environments (Benvenuto et al., 2015), as well as evaluate the prevalence of molecular convergence and the patterns it might follow in anchialine caves, where strong selective pressures could prompt for homologous mechanisms of genetic adaptation across different taxa.

Molecular studies of the evolution of special adaptations to extreme environments have been undertaken in a wide array of taxa; although to date most of these have focused on prokaryotes (Lauro \& Bartlett, 2008; Sahl et al., 2011; BonillaRosso et al., 2012; Lesniewski et al., 2012; Baker et al., 2012, 2013; Orsi et al., 2013; Iwanaga et al., 2014), plants (Gidekel et al., 2003; Dassanayake et al., 2009; Deyholos, 2010; Champigny et al., 2013; Liu et al., 2013; Torales et al., 2013), and vertebrates (Wilcox et al., 2004; Protas et al., 2006; Qiu et al., 2012; Gross et al., 2013). However, recent NGS efforts that specifically target crustaceans in extreme environments have been embarked upon with very promising results (for examples see: Clark et al., 
2011, Antarctic waters; Protas et al., 2011, freshwater caves; Harms et al., 2013, Arctic waters; von Reumont et al., 2014, anchialine caves; Wong et al., 2015, deep sea). For instance, Hinaux et al. (2013) used RNASeq to show that the loss of vision in the Mexican cavefish Astyanax fasciatus is probably due to relaxed selective pressures on their visual genes, which showed numerous deleterious mutations. A similar occurrence was reported by Tierney et al. (2015), who analyzed the transcriptomes of three cave-dwelling beetles and found evidence of convergent loss of opsin photoreceptor transcription by neutral processes. Likewise, von Reumont et al. (2014) pioneered one of the first examinations of an anchialine crustacean transcriptome, and revealed that the remipede Xibalbanus tulumensis (Yager, 1987) is capable of producing and utilizing venom proteins for predation. This discovery not only provides evidence for the first and only venomous crustacean documented, but also illustrates the potential that NGS technologies offer to the biological and evolutionary study of anchialine cave ecosystems.

\section{CONCLUDING REMARKS}

Anchialine caves are unique ecosystems with highly specialized inhabitants, which are often endemic (Iliffe, 2002). As such, these unique ecosystems function as natural laboratories (Mejía-Ortíz \& Hartnoll, 2006; Gonzalez et al., 2011) that allow us to test numerous hypotheses concerning adaptation, speciation, and evolution. Furthermore, cave ecosystems present us with the opportunity to study organisms existing in habitats and conditions perhaps analogous to those of our planet many millions of years ago (Por, 2007). The special adaptations and evolutionary processes that gave rise to extant extremophiles, including some cave organisms, grant us the ability to examine questions regarding the origin and early evolution of life on our planet, and applications relating to these (i.e., astrobiology, Christin et al., 2010; Czyżewska, 2011; Gonzalez et al., 2011; Protas et al., 2011; Bonilla-Rosso et al., 2012). The unique processes and characteristics of anchialine caves (distribution, biogeochemistry and habitat stratification, chemosynthetic food-webs) and their biodiversity make them important communities to conserve in face of current anthropogenic threats (Myers et al., 2000; Iliffe, 2002; Porter, 2007; Mercado-Salas et al., 2013). Unfortunately, anchialine caves are often found in conflict with the impacts of anthropogenic forces such as tourism-driven habitat loss, pollution by sewage, overexploitation of aquifers, climate change, and others (Iliffe et al., 1984; Sket, 1999; Iliffe, 2002). The distribution of these coastal caves in 'desirable' locations in the tropics often places them at a considerable disadvantage (Iliffe, 2002). Numerous stygobiont species follow patterns of regional and even single-cave endemicity (Sket, 1999; De Grave et al., 2007), making them more prone to be severely impacted and becoming extinct as a result of pollution and habitat destruction. The opportunity to document and study anchialine cave biodiversity and evolution is a fleeting one (Wilson, 1985; Iliffe, 2002) and the potential for substantial discoveries is under threat of rapid decline and eventual disappearance.

Even though biological research in caves has seen significant advances in recent decades, new and emerging genomic technologies have just begun to scratch the surface of the underworld's deepest mysteries. The adoption of these technologies not only will considerably expand the breadth of scientific questions that can be addressed and the depth with which these can be answered, but will surely provide us with necessary knowledge and tools to manage and conserve these intriguing and threatened habitats and their unique biodiversity.

\section{ACKNOWLEDGEMENTS}

We would like to thank Dr. José María Eirín-López and Dr. Kalai Mathee (Florida International University) for their valuable comments during the preparation of this manuscript. We are also grateful to Joseph SongLópez, Jill Heinerth, and Tamara Thomsen for their diagrams and photographs of anchialine systems. This research was made possible in part by a grant from The Gulf of Mexico Research Initiative. Iliffe's anchialine cave research has been supported by grants from the National Science Foundation, NOAA, and National Geographic Society, among others. This is contribution \#3 of the Marine Education and Research Center of the Institute for Water and the Environment at Florida International University.

\section{REFERENCES}

Adams M. \& Humphreys W., 1993 - Patterns of genetic diversity within selected subterranean fauna of the Cape Range peninsula, Western Australia: systematic and biogeographic implications. Records of the Western Australian Museum, Supplement, 45: 145-164.

Álvarez F., Iliffe T.M. \& Villalobos J.L., 2006 Macromaxillocarididae, a new family of stenopodidean shrimp from an anchialine cave in the Bahamas, with the description of Macromaxillocaris bahamaensis, $n$. gen. Journal of Crustacean Biology, 26 (3): 366-378. http://dx.doi.org/10.1651/C-2658.1

Álvarez F., Iliffe T.M., Gonzalez B. \& Villalobos J.L., 2012 - Triacanthoneus akumalensis, a new species of alpheid shrimp (Crustacea: Caridea: Alpheidae) from an anchialine cave in Quintana Roo, Mexico. Zootaxa, 68: 61-68.

Álvarez F., Villalobos J.L., Hendrickx M.E., EscobarBriones E., Rodríguez-Almaraz G. \& Campos E., 2014 - Biodiversidad de crustáceos decápodos (Crustacea: Decapoda) en México. Revista Mexicana de Biodiversidad, 85: S208-S219.

http://dx.doi.org/10.7550/rmb.38758

Anders F., 1956 - Über Ausbildung und Vererbung der Körperfarbe bei Gammarus pulex ssp. subterraneus (Schneider), einer normalerweise pigmentlosen Höhlenform des gemeinen Bachflohkrebses. Zeitschrift für Induktive Abstammungs- und Vererbungslehre, 87: $567-579$.

Arendt J. \& Reznick D., 2008 - Convergence and parallelism reconsidered: what have we learned about the genetics of adaptation? Trends in Ecology \& Evolution, 23 (1): 26-32.

http://dx.doi.org/10.1016/j.tree.2007.09.011 
Baker B.J., Lesniewski R.A. \& Dick G.J., 2012 - Genomeenabled transcriptomics reveals archaeal populations that drive nitrification in a deep-sea hydrothermal plume. The ISME Journal, 6 (12): 2269-2279. http://dx.doi.org/10.1038/ismej.2012.64

Baker B.J., Sheik C.S., Taylor C.A., Jain S., Bhasi A., Cavalcoli J.D. \& Dick G.J., 2013 - Community transcriptomic assembly reveals microbes that contribute to deep-sea carbon and nitrogen cycling. The ISME Journal, 7 (10): 1962-1973.

http://dx.doi.org/10.1038/ismej.2013.85

Baratti M., Filippelli M., Nardi F., Messana G., 2010 - Molecular phylogenetic relationships among some stygobitic cirolanid species (Crustacea, Isopoda). Contributions to Zoology, 79 (2): 57-67.

Bauermeister J., Ramette A. \& Dattagupta S., 2012 - Repeatedly evolved host-specific ectosymbioses between sulfur-oxidizing bacteria and amphipods living in a cave ecosystem. PLoS ONE, 7 (11): e50254.

http://dx.doi.org/10.1371/journal.pone.0050254

Beatty R., 1949 - The pigmentation of cavernicolous animals. III. The carotenoid pigments of some amphipod crustacea. Journal of Experimental Biology, 26: 125-130.

Becking L.E., Renema W., Santodomingo N.K., Hoeksema B.W., Tuti Y. \& Voogd N.J., 2011 - Recently discovered landlocked basins in Indonesia reveal high habitat diversity in anchialine systems. Hydrobiologia, 677 (1): 89-105. http://dx.doi.org/10.1007/s10750-011-0742-0

Beddows P. \& Hendrickson M., 2008 - When the survey is not enough: temperature, salinity, and dye tracing reveal flow paths. Proceedings of the 2007 National Cave and Karst Management Symposium, p. 198-203.

Beddows P.A., Smart P.L., Whitaker F.F. \& Smith S.L., 2007 - Decoupled fresh-saline groundwater circulation of a coastal carbonate aquifer: Spatial patterns of temperature and specific electrical conductivity. Journal of Hydrology, 346: 18-32.

http://dx.doi.org/10.1016/j.jhydrol.2007.08.013

Benvenuto C., Knott B. \& Weeks S., 2015 - Crustaceans of extreme environments. In: Thiel M. \& Watling L. (Eds.), The Natural History of the Crustacea. Oxford University Press, New York, p. 379-417.

Bickford D., Lohman D.J., Sodhi N.S., Ng P.K.L., Meier R., Winker K., Ingram K.K. \& Das I., 2007 - Cryptic species as a window on diversity and conservation. Trends in Ecology \& Evolution, 22 (3): 148-155. http://dx.doi.org/10.1016/j.tree.2006.11.004

Binladen J., Gilbert M.T.P., Bollback J.P., Panitz F., Bendixen C., Nielsen R. \& Willerslev E., 2007 - The use of coded PCR primers enables high-throughput sequencing of multiple homolog amplification products by 454 parallel sequencing. PLoS ONE, 2 (2): e197. http://dx.doi.org/10.1371/journal.pone.0000197

Bishop R.E. \& Iliffe T.M., 2012 - Ecological physiology of the anchialine shrimp Barbouria cubensis: $a$ comparison of epigean and hypogean populations. Marine Biodiversity, 42 (3): 303-310. http://dx.doi.org/10.1007/s12526-012-0113-8

Bishop R.E., Humphreys W.F., Cukrov N., Žic V., Boxshall G.A., Cukrov M., Iliffe T.M., Kršinić F., Moore W.S., Pohlman J.W. \& Sket B., 2015 - "Anchialine" redefined as a subterranean estuary in a crevicular or cavernous geological setting. Journal of Crustacean Biology, 35 (4): 511-514.

http://dx.doi.org/10.1163/1937240X-00002335

Bonilla-Rosso G., Peimbert M., Alcaraz L.D., Hernández I., Eguiarte L.E., Olmedo-Alvarez G. \& Souza V., 2012 Comparative metagenomics of two microbial mats at Cuatro Ciénegas Basin II: community structure and composition in oligotrophic environments. Astrobiology, 12 (7): 659-73.

http://dx.doi.org/10.1089/ast.2011.0724
Botello A., Iliffe T.M., Alvarez F., Juan C., Pons J. \& Jaume D., 2013 - Historical biogeography and phylogeny of Typhlatya cave shrimps (Decapoda: Atyidae) based on mitochondrial and nuclear data. Journal of Biogeography, 40 (3): 594-607. http://dx.doi.org/10.1111/jbi.12020

Botoşăneanu L. \& Iliffe T.M., 2006 - A new species of stygobitic cirolanid (Isopoda: Cirolanidae) from an anchialine cave on Abaco, the Bahamas. Bulletin de L'Institut Royal des Sciences Naturelles de Belgique, 76: 27-31.

Bowman T. \& Iliffe T.M., 1985 - Mictocaris halope, a new unusual peracaridan crustacean from marine caves on Bermuda. Journal of Crustacean Biology, 5 (1): 58-73. http://dx.doi.org/10.2307/1548220

Bowman T., Yager J. \& Iliffe T.M., 1985 - Speonebalia cannoni, n. gen., n. sp., from the Caicos Islands, the first hypogean leptostracan (Nebaliacea: Nebaliidae). Proceedings of the Biological Society of Washington, 98 (2): 439-446.

Boxshall G.A. \& Defaye D., 2008 - Global diversity of copepods (Crustacea: Copepoda) in freshwater. Hydrobiologia, 595 (1): 195-207. http://dx.doi.org/10.1007/s 10750-007-9014-4

Boxshall G.A. \& Huys R., 1989 - New tantulocarid, Stygotantulus stocki, parasitic on harpacticoid copepods, with an analysis of the phylogenetic relationships within the Maxillopoda. Journal of Crustacean Biology, 9: 126-140.

http:/ /dx.doi.org/10.2307/1548454

Bracken H.D., De Grave S., Toon A., Felder D.L. \& Crandall K.A., 2010 - Phylogenetic position, systematic status, and divergence time of the Procarididea (Crustacea: Decapoda). Zoologica Scripta, 39 (2): 198-212. http://dx.doi.org/10.1111/j.1463-6409.2009.00410.x

Bracken-Grissom H.D., Felder D.L., Vollmer N.L., Martin J.W. \& Crandall K.A., 2012 - Phylogenetics links monster larva to deep-sea shrimp. Ecology and Evolution, 2 (10): 2367-73. http://dx.doi.org/10.1002/ece3.347

Bradbury I.R., Hamilton L.C., Dempson B., Robertson M.J., Bourret V., Bernatchez L. \& Verspoor E., 2015 - Transatlantic secondary contact in Atlantic Salmon, comparing microsatellites, a single nucleotide polymorphism array and restriction-site associated DNA sequencing for the resolution of complex spatial structure. Molecular Ecology, 24 (20): 5130-5144. http://dx.doi.org/10.1111/mec.13395

Bribiesca-Contreras G., Solís-Marín F.A., LaguardaFigueras A. \& Zaldivar-Riverón A., 2013 -Identification of echinoderms (Echinodermata) from an anchialine cave in Cozumel Island, Mexico, using DNA barcodes. Molecular Ecology Resources, 13 (6): 1137-1145. http:/ / dx.doi.org/10.1111/1755-0998.12098

Brooks H.K., 1955 - A crustacean from the Tesnus Formation (Pennsylvanian) of Texas. Journal of Paleontology, 29 (5): 852-856.

Bruce A.J. \& Davie P., 2006 - new anchialine shrimp of the genus Procaris from Christmas Island: the first occurrence of the Procarididae in the Indian Ocean (Crustacea: Decapoda: Caridea. Zootaxa, 1238: 23-33.

Bruce N.L. \& Humphreys W.F. 1993 - Haptolana pholeta, $s p$. nov., the first subterranean flabelliferan isopod crustacean (Cirolanidae) from Australia. Invertebrate Taxonomy, 7: 875-884. http://dx.doi.org/10.1071/IT9930875

Buhay J.E. \& Crandall K.A., 2005 - Subterranean phylogeography of freshwater crayfishes shows extensive gene flow and surprisingly large population sizes. Molecular Ecology, 14: 4259-4273. http://dx.doi.org/10.1111/j.1365-294X.2005.02755.x 
Bybee S.M., Bracken-Grissom H.D., Haynes B.D., Hermansen R.A., Byers R.L., Clement M.J., Udall J.A., Wilcox E.R. \& Crandall K.A., 2011 a-Targeted amplicon sequencing (TAS): a scalable next-gen approach to multilocus, multitaxa phylogenetics. Genome Biology and Evolution, 3: 1312-1323.

http://dx.doi.org/10.1093/gbe/evr106

Bybee S.M., Bracken-Grissom H.D., Hermansen R.A., Clement M.J., Crandall K.A. \& Felder D.L., 2011b Directed next generation sequencing for phylogenetics: An example using Decapoda (Crustacea). Zoologischer Anzeiger - A Journal of Comparative Zoology, 250 (4): 497-506. http://dx.doi.org/10.1016/j.jcz.2011.05.010

Cabezas P., Alda F., Macpherson E. \& Machordom A., 2012 - Genetic characterization of the endangered and endemic anchialine squat lobster Munidopsis polymorpha from Lanzarote (Canary Islands): management implications. ICES Journal of Marine Science, 69 (6): 1030-1037.

http://dx.doi.org/10.1093/icesjms/fss062

Caccone A. \& Sbordoni V., 2001 - Molecular biogeography of cave life: a study using mitochondrial DNA from bathysciine beetles. Evolution, 55 (1): 122-130. http://dx.doi.org/10.1111/j.0014-3820.2001.tb01278.x

Castoe T.A., de Koning A.P.J. \& Pollock D.D., 2010 Adaptive molecular convergence. Molecular evolution versus molecular phylogenetics. Communicative \& Integrative Biology, 3 (1): 67-69. http://dx.doi.org/10.4161/cib.3.1.10174

Chace F.A. \& Manning R.B., 1972 - Two new caridean shrimps, one representing a new family, from marine pools on Ascension Island (Crustacea: Decapoda: Natantia). Smithsonian Contributions to Zoology, 131: 1-18.

http://dx.doi.org/10.5479/si.00810282.131

Champigny M.J., Sung W.W., Catana V., Salwan R., Summers P.S., Dudley S.A., Provart N.J., Cameron R.K., Golding G.B. \& Weretilnyk E.A., 2013 - RNASeq effectively monitors gene expression in Eutrema salsugineum plants growing in an extreme natural habitat and in controlled growth cabinet conditions. BMC Genomics, 14: 578.

http://dx.doi.org/10.1186/1471-2164-14-578

Christin P.A., Weinreich D.M. \& Besnard G., 2010 - Causes and evolutionary significance of genetic convergence. Trends in Genetics, 26: 400-405.

http://dx.doi.org/10.1016/j.tig.2010.06.005

Clark M.S., Thorne M.A.S., Toullec J.-Y., Meng Y., Guan L.L., Peck L.S. \& Moore S., 2011 - Antarctic krill 454 pyrosequencing reveals chaperone and stress transcriptome. PLoS ONE, 6 (1): e15919.

http://dx.doi.org/10.1371/journal.pone.0015919

Coghill L.M., Darrin Hulsey C., Chaves-Campos J., García de Leon F.J. \& Johnson S.G., 2014 - Next generation phylogeography of cave and surface Astyanax mexicanus. Molecular Phylogenetics and Evolution, 79 (1): 368-374.

http://dx.doi.org/10.1016/j.ympev.2014.06.029

Corbera J., Segonzac M. \& Cunha M.R., 2008 - A new deep-sea genus of Nannastacidae (Crustacea, Cumacea) from the Lucky Strike hydrothermal vent field (Azores Triple Junction, Mid-Atlantic Ridge). Marine Biology Research, 4 (3): 180-192.

http://dx.doi.org/10.1080/17451000801898576

Corey S., 1981 - Comparative fecundity and reproductive strategies in seventeen species of the Cumacea (Crustacea: Peracarida). Marine Biology, 62 (1): 65-72. http://dx.doi.org/10.1007/BF00396952
Cronn R., Knaus B.J., Liston A., Maughan P.J., Parks M., Syring J. V \& Udall J., 2012 - Targeted enrichment strategies for next-generation plant biology. American Journal of Botany, 99 (2): 291-311.

http://dx.doi.org/10.3732/ajb.1100356

Culver D.C. \& Pipan T., 2009 - The Biology of Caves and Other Subterranean Habitats. Oxford University Press, New York, USA.

Culver D. \& Sket B., 2000 - Hotspots of subterranean biodiversity in caves and wells. Journal of Cave and Karst Studies, 62 (1): 11-17.

Culver D., Kane T.C. \& Fong D., 1995 - Adaptation and Natural Selection in Caves: The Evolution of Gammarus minus. Harvard University Press, Cambridge, Massachusetts.

Culver D.C., Pipan T. \& Schneider K., 2009 - Vicariance, dispersal and scale in the aquatic subterranean fauna of karst regions. Freshwater Biology, 54 (4): 918-929. http://dx.doi.org/10.1111/j.1365-2427.2007.01856.x

Czyżewska U.K., 2011 - Exploring knowledge about microbes living in the extreme environments - the resources review. ELBA Bioflux, 3 (1): 27-37.

Daenekas J., Iliffe T.M., Yager J. \& Koenemann S., 2009 - Speleonectes kakuki, a new species of Remipedia (Crustacea) from anchialine and sub-seafloor caves on Andros and Cat Island, Bahamas. Zootaxa, 2016: 51-66.

Danielopol D., 1981 - Distribution of ostracods in the groundwater of the North Western Coast of Euboea (Greece). International Journal of Speleology, 11: 91-103. http:/ /dx.doi.org/10.5038/1827-806X.11.1.10

Dassanayake M., Haas J.S., Bohnert H.J. \& Cheeseman J.M., 2009 - Shedding light on an extremophile lifestyle through transcriptomics. The New Phytologist, 183 (3): 764-775.

http://dx.doi.org/10.1111/j.1469-8137.2009.02913.x

Dattagupta S., Schaperdoth I., Montanari A., Mariani S., Kita N., Valley J.W. \& Macalady J.L., 2009 - A novel symbiosis between chemoautotrophic bacteria and a freshwater cave amphipod. The ISME Journal, 3 (8): 935-943. http://dx.doi.org/10.1038/ismej.2009.34

Davey J.W. \& Blaxter M.L., 2010 - RADSeq: nextgeneration population genetics. Briefings in Functional Genomics, 9 (5): 416-423.

http://dx.doi.org/10.1093/bfgp/elq031

Davey J.W., Hohenlohe P.A., Etter P.D., Boone J.Q., Catchen J.M. \& Blaxter M.L., 2011 - Genome-wide genetic marker discovery and genotyping using nextgeneration sequencing. Nature Reviews Genetics, 12 (7): 499-510. http://dx.doi.org/10.1038/nrg3012

De Grave S., Cai Y. \& Anker A., 2007 - Global diversity of shrimps (Crustacea: Decapoda: Caridea) in freshwater. Hydrobiologia, 595 (1): 287-293.

http://dx.doi.org/10.1007/s10750-007-9024-2

Desutter-Grandcolas L., 1997 - Studies in cave life evolution: a rationale for future theoretical developments using phylogenetic inference. Journal of Zoological Systematics and Evolutionary Research, 35: 23-31. http://dx.doi.org/10.1111/j.1439-0469.1997.tb00400.x

De Wit P., Pespeni M.H., Ladner J.T., Barshis D.J., Seneca F., Jaris H., Therkildsen N.O., Morikawa M. \& Palumbi S.R., 2012 - The simple fool's guide to population genomics via RNA-Seq: an introduction to high-throughput sequencing data analysis. Molecular Ecology Resources, 12 (6): 1058-1067.

http://dx.doi.org/10.1111/1755-0998.12003

Deyholos M.K., 2010 - Making the most of drought and salinity transcriptomics. Plant, Cell and Environment, 33: 648-654.

http://dx.doi.org/10.1111/j.1365-3040.2009.02092.x 
Dickson G.W., 1975 - A preliminary study of heterotrophic microorganisms as factors in substrate selection of troglobitic invertebrates. The NSS Bulletin, 37 (4): 89-93.

Dubilier N., Bergin C. \& Lott C., 2008 - Symbiotic diversity in marine animals: the art of harnessing chemosynthesis. Nature Reviews Microbiology, 6 (10): 725-740. http://dx.doi.org/10.1038/nrmicro1992

Duncan T.K., 1984 - Life history of Almyracuma proximoculo Jones and Burbanck, 1959 (Crustacea: Cumacea) from intertidal fresh-water springs on Cape Cod, Massachusetts. Journal of Crustacean Biology, 4 (3): 356-374. http://dx.doi.org/10.2307/1548036

Ekblom R. \& Galindo J., 2011 - Applications of next generation sequencing in molecular ecology of nonmodel organisms. Heredity, 107 (1): 1-15.

http://dx.doi.org/10.1038/hdy.2010.152

Ellegren H., 2008 - Sequencing goes 454 and takes large-scale genomics into the wild. Molecular Ecology, 17 (7): 1629-1635.

http://dx.doi.org/10.1111/j.1365-294X.2008.03699.x

Emerson M.J., 1991 - Remipedia: Part 2 Paleontology. San Diego Society of Natural History.

Engel A.S., 2007 - Observations on the biodiversity of sulfidic karst habitats. Journal of Cave and Karst Studies, 69 (1): 187-206.

Engel A.S., Porter M.L., Stern L.A., Quinlan S. \& Bennett P.C., 2004 - Bacterial diversity and ecosystem function of filamentous microbial mats from aphotic (cave) sulfidic springs dominated by chemolithoautotrophic "Epsilonproteobacteria". FEMS Microbiology Ecology, 51 (1): 31-53.

http://dx.doi.org/10.1016/j.femsec.2004.07.004

Espinasa L. \& Borowsky R.B., 2001 - Origins and relationship of cave populations of the blind Mexican tetra, Astyanax fasciatus, in the Sierra de El Abra. Environmental Biology of Fishes, 62 (1-3): 233-237. http://dx.doi.org/10.1023/A:1011881921023

Felgenhauer B.E., Abele L.G. \& Kim W., 1988 Reproductive morphology of the anchialine shrimp Procaris ascensionis (Decapoda: Procarididae). Journal of Crustacean Biology, 8 (3): 333-339. http://dx.doi.org/10.2307/1548272

Figueroa D.F., 2011 - Phylogenetic analysis of Ridgewayia (Copepoda: Calanoida) from the Galapagos and of a new species from the Florida Keys with a reevaluation of the phylogeny of Calanoida. Journal of Crustacean Biology, 31 (1): 153-165.

http://dx.doi.org/10.1651/10-3341.1

Finston T.L., Johnson M.S., Humphreys W.F., Eberhard S.M. \& Halse S.A., 2007 - Cryptic speciation in two widespread subterranean amphipod genera reflects historical drainage patterns in an ancient landscape. Molecular Ecology, 16 (2): 355-365. http://dx.doi.org/10.1111/j.1365-294X.2006.03123.x

Flot J.F., Wörheide G. \& Dattagupta S., 2010 Unsuspected diversity of Niphargus amphipods in the chemoautotrophic cave ecosystem of Frasassi, central Italy. BMC Evolutionary Biology, 10: 171.

http://dx.doi.org/10.1186/1471-2148-10-171

Floyd R., Abebe E., Papert A. \& Blaxter M., 2002 Molecular barcodes for soil nematode identification. Molecular Ecology, 11 (4): 839-850.

http://dx.doi.org/10.1046/j.1365-294X.2002.01485.x

Foote A.D., Liu Y., Thomas G.W.C., Vinař T., Alföldi J., Deng J., Dugan S., Elk C.E. Van, Hunter M.E., Joshi V., Khan Z., Kovar C., Lee S.L., Lindblad-toh K., Mancia A., Nielsen R., Qin X., Qu J., Raney B.J., et al., 2015 - Convergent evolution of the genomes of marine mammals. Nature Genetics, 47 (3): 272-275.

http://dx.doi.org/10.1038/ng.3198
Fosshagen A. \& Iliffe T.M., 2004 - A new species of caveliving calanoid copepod from Grand Bahama. Sarsia, 89 (5): 346-354.

http://dx.doi.org/10.1080/00364820410002613

Fosshagen A., Boxshall G. \& Iliffe T.M., 2001 - The Epacteriscidae, a cave-living family of calanoid copepods. Sarsia, 86: 245-318.

http://dx.doi.org/10.1080/00364827.2001.10425520

Friedrich M., 2013 - Biological Clocks and Visual Systems in Cave-Adapted Animals at the Dawn of Speleogenomics. Integrative and Comparative Biology, 53 (1): 50-67. http://dx.doi.org/10.1093/icb/ict058

Friedrich M., Chen R., Daines B., Bao R., Caravas J., Rai P.K., Zagmajster M. \& Peck S.B., 2011 Phototransduction and clock gene expression in the troglobiont beetle Ptomaphagus hirtus of Mammoth cave. The Journal of Experimental Biology, 214: 3532-3541. http://dx.doi.org/10.1242/jeb.060368

Genomic Resources Development Consortium, Havird J.C. \& Santos S.R., 2014 - Genomic Resources Notes accepted 1 June 2014 - 31 July 2014. Molecular Ecology Resources, 14 (6): 1322.

http://dx.doi.org/10.1111/1755-0998.12315

Gidekel M., Destefano-Beltrán L., García P., Mujica L., Leal P., Cuba M., Fuentes L., Bravo L.A., Corcuera L.J., Alberdi M., Concha I. \& Gutiérrez A., 2003 Identification and characterization of three novel cold acclimation-responsive genes from the extremophile hair grass Deschampsia antarctica Desv. Extremophiles, 7 (6): 459-469.

http://dx.doi.org/10.1007/s00792-003-0345-4

Gnewuch W. \& Croker R., 1973 - Macroinfauna of northern New England marine sand. I. The biology of Mancocuma stellifera Zimmer, 1943 (Crustacea: Cumacea). Canadian Journal of Zoology, 51 (10): 1011-1020. http://dx.doi.org/10.1139/z73-147

Goffredi S.K., 2010 - Indigenous ectosymbiotic bacteria associated with diverse hydrothermalvent invertebrates. Environmental Microbiology Reports, 2 (4): 479-488. http://dx.doi.org/10.1111/j.1758-2229.2010.00136.x

Gonzalez B.C., Iliffe T.M., Macalady J.L., Schaperdoth I. \& Kakuk B., 2011 - Microbial hotspots in anchialine blue holes: initial discoveries from the Bahamas. Hydrobiologia, 677 (1): 149-156. http://dx.doi.org/10.1007/s10750-011-0932-9

Gràcia F. \& Jaume D., 2011 - La fauna aquàtica dels hàbitats anquihalins $i$ dolçaquícoles de les cavitats balears. ENDINS, 35: 257-268.

Groh K.C., Vogel H., Stensmyr M.C., Grosse-Wilde E. \& Hansson B.S., 2014 - The hermit crab's nose - antennal transcriptomics. Frontiers in Neuroscience, 7: 266.

http://dx.doi.org/10.3389/fnins.2013.00266

Gross J.B., Furterer A., Carlson B.M. \& Stahl B.A., 2013 - An integrated transcriptome-wide analysis of cave and surface dwelling Astyanax mexicanus. PLoS ONE, 8 (2): e55659.

http://dx.doi.org/10.1371/journal.pone.0055659

Grover C.E., Salmon A. \& Wendel J.F., 2012 - Targeted sequence capture as a powerful tool for evolutionary analysis. American Journal of Botany, 99 (2): 312-319. http://dx.doi.org/10.3732/ajb.1100323

Guțu M. \& Iliffe T.M., 1989a-Description of two new species of Tanaidacea (Crustacea) from the marine water caves of the Palau Islands (Pacific Ocean). Travaux du Muséum National d'Histoire Naturelle "Grigore Antipa." 30: $169-180$.

Guțu M. \& Iliffe T.M., 1989b - Apseudes orghidani, a new species of Tanaidacea (Crustacea) from an anchialine cave on Bermuda. Travaux du Muséum National d'Histoire Naturelle "Grigore Antipa." 30: 161-167. 
Guțu M. \& Iliffe T.M., 1998 - Description of a new hirsutiid (ng, n. sp.) and reassignment of this family from order Mictacea to the new order, Bochusacea (Crustacea, Peracarida). Travaux du Muséum National d'Histoire Naturelle "Grigore Antipa." 40: 93-120.

Guțu M. \& Iliffe T.M., 2011 - Leptochelia vatulelensis (Crustacea: Tanaidacea), a new species from anchialine caves of the South-Western Pacific. Travaux du Muséum National d'Histoire Naturelle "Grigore Antipa." 54 (2): 351-363.

Hajibabaei M., Singer G.A.C., Hebert P.D.N. \& Hickey D.A., 2007 - DNA barcoding: how it complements taxonomy, molecular phylogenetics and population genetics. Trends in Genetics, 23 (4): 167-172.

http://dx.doi.org/10.1016/j.tig.2007.02.001

Hancock-Hanser B.L., Frey A., Leslie M.S., Dutton P.H., Archer F.I. \& Morin P.A., 2013 - Targeted multiplex next-generation sequencing: advances in techniques of mitochondrial and nuclear DNA sequencing for population genomics. Molecular Ecology Resources, 13 (2): 254-268.

http://dx.doi.org/10.1111/1755-0998.12059

Harms L., Frickenhaus S., Schiffer M., Mark F.C., Storch D., Pörtner H.O., Held C. \& Lucassen M., 2013 Characterization and analysis of a transcriptome from the boreal spider crab Hyas araneus. Comparative Biochemistry and Physiology, Part D, 8 (4): 344-351.

Harr B. \& Turner L.M., 2010 - Genome-wide analysis of alternative splicing evolution among Mus subspecies. Molecular Ecology, 19 (1): 228-239.

http://dx.doi.org/10.1111/j.1365-294X.2009.04490.x

Hedges D.J., Guettouche T., Yang S., Bademci G., Diaz A., Andersen A., Hulme W.F., Linker S., Mehta A., Edwards Y.J.K., Beecham G.W., Martin E.R., PericakVance M.A., Zuchner S., Vance J.M. \& Gilbert J.R., 2011 - Comparison of three targeted enrichment strategies on the SOLiD sequencing platform. PLoS ONE, 6 (4): e18595.

http://dx.doi.org/10.1371/journal.pone.0018595

Hinaux H., Poulain J., Da Silva C., Noirot C., Jeffery W.R., Casane D. \& Rétaux S., 2013 - De novo sequencing of Astyanax mexicanus surface fish and Pachón cavefish transcriptomes reveals enrichment of mutations in cavefish putative eye genes. PLoS ONE, 8 (1): e53553. http://dx.doi.org/10.1371/journal.pone.0053553

Hobbs H.H., 2012 - Crustacea. In: White W.B. \& Culver D.C. (Eds.) Encyclopedia of Caves. Elsevier Academic Press, Amsterdam, Netherlands, p. 141-153. http://dx.doi.org/10.1016/B978-0-12-383832-2.00027-X

Hobbs H.H. \& Daniel M.A., 1977 - A review of the troglobitic decapod crustaceans of the Americas. Smithsonian Contributions to Zoology, 244: 1-183. http://dx.doi.org/10.5479/si.00810282.244

Hoenemann M., Neiber M.T., Humphreys W., Iliffe T.M., Li D., Schram F.R. \& Koenemann S., 2013 - Phylogenetic analysis and systematic revision of Remipedia (Nectiopoda) from Bayesian analysis of molecular data. Journal of Crustacean Biology, 33 (5): 603-619. http://dx.doi.org/10.1163/1937240X-00002179

Humphreys W., 1999 - Physico-chemical profile and energy fixation in Bundera Sinkhole, an anchialine remiped habitat in north-western Australia. Journal of the Royal Society of Western Australia, 82: 89-98.

Humphreys W., 2001a - Milyeringa veritas (Eleotridae), a remarkably versatile Cave Fish from the Arid Tropics of Northwestern Australia. Environmental Biology of Fishes, 62 (1): 297-313.

http://dx.doi.org/10.1023/A:1011880726946
Humphreys W., 2001b - Groundwater calcrete aquifers in the Australian arid zone: the context to an unfolding plethora of stygal biodiversity. Records of the Western Australian Museum, Supplement, 64: 63-83.

Humphreys W., 2002 - The subterranean fauna of Barrow Island, northwestern Australia, and its environment. Mémoires de biospéologie, 28: 107-127.

Humphreys W. \& Danielopol D., 2006 - Danielopolina (Ostracoda, Thaumatocyprididae) on Christmas Island, Indian Ocean, a sea mount island. Crustaceana, 78 (11): 1339-1352.

http://dx.doi.org/10.1163/156854005776759861

Humphreys W., Tetu S., Elbourne L., Gillings M., Seymour J., Mitchell J. \& Paulsen I., 2012 - Geochemical and microbial diversity of Bundera sinkhole, an anchialine system in the eastern Indian ocean. Natura Croatica, 21 (1): 59-63.

Hunter R.L., Webb M.S., Iliffe T.M. \& Alvarado Bremer J.R., 2007 - Phylogeny and historical biogeography of the cave-adapted shrimp genus Typhlatya (Atyidae) in the Caribbean Sea and western Atlantic. Journal of Biogeography, 35: 65-75.

http://dx.doi.org/10.1111/j.1365-2699.2007.01767.x

Huys R., 1990 - Campyloxiphos dineti gen. et spec. nov. from off Namibia and a redefinition of the Deoterthridae Boxshall and Lincoln (Crustacea: Tantulocarida). Journal of Natural History, 24 (2): 415-432. http://dx.doi.org/10.1080/00222939000770311

Huys R., Llewellyn-Hughes J., Olson P.D. \& Nagasawa K., 2006 - Small subunit rDNA and Bayesian inference reveal Pectenophilus ornatus (Copepoda incertae sedis) as highly transformed Mytilicolidae, and support assignment of Chondracanthidae and Xarifiidae to Lichomolgoidea (Cyclopoida). Biological Journal of the Linnean Society, 87 (3): 403-425.

http://dx.doi.org/10.1111/j.1095-8312.2005.00579.x Ichihashi Y., Aguilar-Martínez J.A., Farhi M., Chitwood D.H., Kumar R., Millon L. V, Peng J., Maloof J.N. \& Sinha N.R., 2014 - Evolutionary developmental transcriptomics reveals a gene network module regulating interspecific diversity in plant leaf shape. Proceedings of the National Academy of Sciences of the United States of America, 111 (25): E2616-E2621.

http://dx.doi.org/10.1073/pnas.1402835111

Iglikowska A. \& Boxshall G.A., 2013 - Danielopolina revised: Phylogenetic relationships of the extant genera of the family Thaumatocyprididae (Ostracoda: Myodocopa). Zoologischer Anzeiger, 252 (4): 469-485. http://dx.doi.org/10.1016/j.jcz.2013.01.004

Iliffe T.M., 1991 - Anchialine fauna of the Galápagos Islands. In: James M.J. (Ed.), Galapagos Marine Invertebrates. Springer, New York, p. 209-231. http://dx.doi.org/10.1007/978-1-4899-0646-5 11

Iliffe T.M., 1992 - Anchialine cave biology. In: Camacho A.I. (Ed.), The Natural History of Biospeleology. Museo Nacional de Ciencias Naturales. Madrid, p. 614-636.

Iliffe T.M., 1993 - Fauna troglobia acuática de la Península de Yucatán. In: Salazar-Vallejo S. \& Gonzalez N. (Eds.), Biodiversidad Marina Y Costera de México. Biodiversidad marina y costera de México. Comisión Nacional para el Conocimiento y Uso de la Biodiversidad y Centro de Investigaciones de Quintana Roo. Mexico, p. 673-686.

Iliffe T.M., 2000 - Anchialine cave ecology. In: Wilkens H., Culver D.C. \& Humphreys W.F. (Eds.), Ecosystems of the World. Subterranean Ecosystems. Elsevier Science, Amsterdam, Netherlands, p. 59-76.

Iliffe T.M., 2002 - Conservation of anchialine cave biodiversity. Proceedings of the Symposium Karst Frontiers, 7: 99-102. 
Iliffe T.M., 2012 - Diving investigations of Bermuda's deep water caves. Natura Croatica, 21 (1): 64-67.

Iliffe T.M. \& Botoşăneanu L., 2006 - The remarkable diversity of subterranean Cirolanidae (Crustacea: Isopoda) in the peri-Caribbean and Mexican Realm. Bulletin de L'Institut Roy al des Sciences Naturelles de Belgique, 76: 5-26.

Iliffe T.M. \& Bowen C., 2001 - Scientific cave diving. Marine Technology Society Journal, 35 (2): 36-41. http://dx.doi.org/10.4031/002533201788001901

Iliffe T.M. \& Kornicker L.S., 2009 - Worldwide diving discoveries of living fossil animals from the depths of anchialine and marine caves. In: Lang M.A., Macintyre I.G. \& Rützler K. (Eds.), Proceedings of the Smithsonian Marine Science Symposium. Smithsonian Contributions to the Marine Sciences, p. 269-280.

Iliffe T.M., Jickells T. \& Brewer M., 1984 - Organic pollution of an inland marine cave from Bermuda. Marine Environmental Research, 12: 173-189. http://dx.doi.org/10.1016/0141-1136(84)90002-3

Iwanaga N., Ide K., Nagashima T., Tomita T., Agari Y., Shinkai A., Kuramitsu S., Okada-Hatakeyema M. Kuzuyama T. \& Nishiyama M., 2014 - Genome-wide comprehensive analysis of transcriptional regulation by ArgR in Thermus thermophilus. Extremophiles, 18 (6): 995-1008.

http:/ /dx.doi.org/10.1007/s00792-014-0669-2

Jaume D. \& Brehier F., 2005 - A new species of Typhlatya (Crustacea: Decapoda: Atyidae) from anchialine caves on the French Mediterranean coast. Zoological Journal of the Linnean Society, 144: 387-414.

http://dx.doi.org/10.1111/j.1096-3642.2005.00175.x

Jaume D. \& Christenson K., 2001 - Amphi-Atlantic distribution of the subterranean amphipod family Metacrangonyctidae (Crustacea, Gammaridea). Contributions to Zoology, 70 (2): 99-125.

Jaume D., Boxshall G.A. \& Humphreys W., 2001 New stygobiont copepods (Calanoida; Misophrioida) from Bundera Sinkhole, an anchialine cenote in northwestern Australia. Zoological Journal of the Linnean Society, 133: 1-24.

http://dx.doi.org/10.1111/j.1096-3642.2001.tb00620.x

Jaume D., Boxshall G.A. \& Bamber R.N., 2006 - A new genus from the continental slope off Brazil and the discovery of the first males in the Hirsutiidae (Crustacea: Peracarida: Bochusacea). Zoological Journal of the Linnean Society, 148: 169-208.

http://dx.doi.org/10.1111/j.1096-3642.2006.00235.x

Jaume D., Pinardo-Moya E. \& Boxshall G.A., $2013-A$ presumed spelaeogriphacean crustacean from an upper Barremian wetland (Las Hoyas; Lower Cretaceous; Central Spain). Palaeontology, 56 (1): 15-28.

http://dx.doi.org/10.1111/j.1475-4983.2012.01144.x

Juan C., Guzik M.T., Jaume D. \& Cooper S.J.B., 2010 - Evolution in caves: Darwin's "wrecks of ancient life" in the molecular era. Molecular Ecology, 19 (18): 3865-3880.

http://dx.doi.org/10.1111/j.1365-294X.2010.04759.x

Justice J.L., Weese D.A., Santos S.R., 2015 - Phylogenetic utility, and variability in structure and content, of complete mitochondrial genomes among genetic lineages of the Hawaiian anchialine shrimp Halocaridina rubra Holthuis 1963 (Atyidae:Decapoda). Mitochondrial DNA. http:/ /dx.doi.org/10.3109/19401736.2015.1046161

Kano Y. \& Kase T., 2004 - Genetic exchange between anchialine cave populations by means of larval dispersal: the case of a new gastropod species Neritilia cavernicola. Zoologica Scripta, 33 (5): 423-437. http://dx.doi.org/10.1111/j.0300-3256.2004.00159.x
Koelbel K., 1892 - Beiträge zur Kenntnis der Crustaceen der Canarischen Inseln. Annalen Des Naturhistorischen Museums in Wien, 7 (3): 105-116.

Koenemann S. \& Iliffe T.M., 2013 - Remipedia. In: von Vaupel Klein J., Charmantier-Daures M., Schram F. (Eds.), Treatise on Zoology - Anatomy, Taxonomy, Biology. The Crustacea, Vol, 4A. Brill. Leiden, Netherlands, p. 125-177.

Koenemann S., Iliffe T.M. \& van der Ham J., 2003 - Three new sympatric species of Remipedia (Crustacea) from Great Exuma Island, Bahamas Islands. Contributions to Zoology, 72 (4): 227-252.

Koenemann S., Iliffe T.M. \& Yager J., 2004 - Kaloketos pilosus, a new genus and species of Remipedia (Crustacea) from the Turks and Caicos Islands. Zootaxa, 12 (618): 1-12.

Koenemann S., Iliffe T.M. \& van der Ham J.L., 2007a Micropacteridae, a new family of Remipedia (Crustacea) from the Turks and Caicos Islands. Organisms Diversity \& Evolution, 7 (1): 52.e1-52.e14.

http://dx.doi.org/10.1016/j.ode.2006.07.002

Koenemann S., Schram F.R., Bloechl A., Iliffe T.M., Hoenemann M. \& Held C., 2007b - Post-embryonic development of remipede crustaceans. Evolution and Development, 9 (2): 117-121.

http://dx.doi.org/10.1111/j.1525-142X.2007.00142.x

Koenemann S., Schram F.R., Honemann M. \& Iliffe T.M., 2007c - Phylogenetic analysis of Remipedia (Crustacea). Organisms Diversity \& Evolution, 7 (1): 33-51. http://dx.doi.org/10.1016/j.ode.2006.07.001

Koenemann S., Bloechl A. \& Martínez A., 2009a - A new, disjunct species of Speleonectes (Remipedia, Crustacea) from the Canary Islands. Marine Biodiversity, 39 (3): 215-225.

http://dx.doi.org/10.1007/s12526-009-0021-8

Koenemann S., Olesen J., Alwes F., Iliffe T.M., Hoenemann M., Ungerer P., Wolff C. \& Scholtz G., 2009b - The post-embryonic development of Remipedia (Crustacea) Additional results and new insights. Development Genes and Evolution, 219 (3): 131-145.

http://dx.doi.org/10.1007/s00427-009-0273-0

Kornicker L.S., Iliffe T.M. \& Harrison-Nelson E., 2007 - Ostracoda (Myodocopa) from anchialine caves and ocean blue holes. Zootaxa, 1565: 1-151.

Kornicker L.S., Iliffe T.M. \& Harrison-Nelson E., 2008 - Ostracoda of Moss Town Blue Hole, Great Exuma Island, Great Bahama Bank (Crustacea: Ostracoda: Myodocopa). Proceedings of the Biological Society of Washington, 121 (2): 237-268.

http://dx.doi.org/10.2988/07-31.1

Kornicker L.S., Iliffe T.M. \& Harrison-Nelson E., 2009 Ontogeny of Deeveya medix Kornicker, 1990 , collected in anchialine and marine caves in the Bahama Islands (Ostracoda: Halocypridae: Deeveyinae). Proceedings of the Biological Society of Washington, 122 (2): 171-205. http://dx.doi.org/10.2988/08-37.1

Krejca J.K., 2005 - Stygobite phylogenetics as a tool for determining aquifer evolution. Unpublished $\mathrm{PhD}$ dissertation, The University of Texas, Austin.

Larson H.K., Foster R., Humphreys W.F. \& Stevens M.I., 2013 - A new species of the blind cave gudgeon Milyeringa (Pisces: Gobioidei, Eleotridae) from Barrow Island, Western Australia, with a redescription of $\mathrm{M}$. veritas Whitley. Zootaxa, 3616 (2): 135-150. http://dx.doi.org/10.11646/zootaxa.3616.2.3

Lauro F.M. \& Bartlett D.H., 2008 - Prokaryotic lifestyles in deep sea habitats. Extremophiles, 12 (1): 15-25. http://dx.doi.org/10.1007/s00792-006-0059-5 
Leaché A.D., Wagner P., Linkem C.W., Böhme W., Papenfuss T.J., Chong R.A., Lavin B.R., Bauer A.M., Nielsen S.V., Greenbaum E., Rödel M.O., Schmitz A., LeBreton M., Ineich I., Chirio L., Ofori-Boateng C., Eniang E.A., Baha El Din S., Lemmon A.R., et al., 2014 - A hybrid phylogenetic-phylogenomic approach for species tree estimation in african agama lizards with applications to biogeography, character evolution, and diversification. Molecular Phylogenetics and Evolution, 79 (1): 215-230.

http://dx.doi.org/10.1016/j.ympev.2014.06.013

Lefébure T., Douady C.J., Malard F. \& Gibert J., 2007 - Testing dispersal and cryptic diversity in a widely distributed groundwater amphipod (Niphargus rhenorhodanensis). Molecular Phylogenetics and Evolution, 42 (3): 676-686.

http://dx.doi.org/10.1016/j.ympev.2006.08.020

Lemmon A.R. \& Lemmon E.M., 2012 - High-throughput identification of informative nuclear loci for shallowscale phylogenetics and phylogeography. Systematic Biology, 61 (5): 745-761.

http://dx.doi.org/10.1093/sysbio/sys051

Lemmon A.R., Emme S.A \& Lemmon E.M., 2012 - Anchored hybrid enrichment for massively highthroughput phylogenomics. Systematic Biology, 61 (5): 727-744.

http://dx.doi.org/10.1093/sysbio/sys049

Lesniewski R.A., Jain S., Anantharaman K., Schloss P.D. \& Dick G.J., 2012 - The metatranscriptome of a deepsea hydrothermal plume is dominated by water column methanotrophs and lithotrophs. The ISME Journal, 6 (12): 2257-2268.

http://dx.doi.org/10.1038/ismej.2012.63

Leys R., Watts C.H., Cooper S.J. \& Humphreys W., 2003 - Evolution of subterranean diving beetles (Coleoptera: Dytiscidae: Hydroporini, Bidessini) in the arid zone of Australia. Evolution, 57 (12): 2819-2834.

http://dx.doi.org/10.1111/j.0014-3820.2003.tb01523.x

Li H. \& Cooper R.L., 2001 - Spatial familiarity in the blind cave crayfish, Orconectes australis packardi. Crustaceana, 74 (5): 417-433.

http://dx.doi.org/10.1163/156854001750243018

Li H. \& Cooper R.L., 2002 - The effect of ambient light on blind cave crayfish: social interactions. Journal of Crustacean Biology, 22 (2): 449-458.

http://dx.doi.org/10.1163/20021975-99990252

Liu S., Wang N., Zhang P., Cong B., Lin X., Wang S., Xia G. \& Huang X., 2013 - Next-generation sequencingbased transcriptome profiling analysis of Pohlia nutans reveals insight into the stress-relevant genes in Antarctic moss. Extremophiles, 17 (3): 391-403.

http://dx.doi.org/10.1007/s00792-013-0528-6

Lorentzen D., Koenemann S. \& Iliffe T.M., 2007 Speleonectes emersoni, a new species of Remipedia (Crustacea) from the Dominican Republic. Zootaxa, 1543: 61-68.

Mamanova L., Coffey A.J., Scott C.E., Kozarewa I., Turner E.H., Kumar A., Howard E., Shendure J. \& Turner D.J., 2010 - Target-enrichment strategies for next-generation sequencing. Nature Methods, 7 (2): 111-118.

http://dx.doi.org/10.1038/nmeth.1419

Martens K., 2004 - Crustacea: Ostracoda. In: Gunn J. (Ed.), Encyclopedia of caves and karst science. Fitzroy Dearborn, New York, p. 267-268.

Martin J. \& Davis G., 2001 - An updated classification of the recent Crustacea. Natural History Museum of Los Angeles County, Los Angeles, California.

Martin J.A. \& Wang Z., 2011 - Next-generation transcriptome assembly. Nature Reviews Genetics, 12 (10): 671-682. http://dx.doi.org/10.1038/nrg3068
McCormack J.E., Maley J.M., Hird S.M., Derryberry E.P., Graves G.R. \& Brumfield R.T., 2012 - Next-generation sequencing reveals phylogeographic structure and a species tree for recent bird divergences. Molecular Phylogenetics and Evolution, 62 (1): 397-406. http://dx.doi.org/10.1016/j.ympev.2011.10.012

McCormack J.E., Hird S.M., Zellmer A.J., Carstens B.C. \& Brumfield R.T., 2013 - Applications of next-generation sequencing to phylogeography and phylogenetics. Molecular Phylogenetics and Evolution, 66 (2): 526-38. http://dx.doi.org/10.1016/j.ympev.2011.12.007

Medina-Gonzalez R., Proudlove G., Chumba-Segura L. \& Iliffe T.M., 2001 - Threatened fishes of the world: Ophisternon infernale (Hubbs, 1938)(Synbranchidae). Environmental Biology of Fishes, 62: 170.

http://dx.doi.org/10.1023/A:1011816312583

Mejía-Ortíz L.M. \& Hartnoll R., 2006 - A new use for useless eyes in cave crustaceans. Crustaceana, 79 (5): 593-600.

http://dx.doi.org/10.1163/156854006777584313

Mejía-Ortíz L.M. \& López-Mejía M., 2005 - Are there adaptation levels to cave life in crayfish? Journal of Crustacean Biology, 25 (4): 593-597.

http://dx.doi.org/10.1651/C-2584.1

Mejía-Ortíz L.M., Hartnoll R.G. \& Viccon-Pale J.A., 2003 - A new stygobitic crayfish from Mexico, Procambarus cavernicola (Decapoda: Cambaridae), with a review of cave-dwelling crayfishes in Mexico. Journal of Crustacean Biology, 23 (2): 391-401.

http://dx.doi.org/10.1163/20021975-99990349

Mejía-Ortíz L.M., Hartnoll R.G. \& López-Mejía M. 2006 Progressive troglomorphism of ambulatory and sensory appendages in three Mexican cave decapods. Journal of Natural History, 40 (5-6): 255-264.

http://dx.doi.org/10.1080/00222930600628382

Mejía-Ortíz L.M., Yánez G. \& López-Mejía M., 2007 Echinoderms in an anchialine cave in Mexico. Marine Ecology, 28: 31-34.

http://dx.doi.org/10.1111/j.1439-0485.2007.00174.x

Mejía-Ortíz L.M., López-Mejía M., Pakes J., Hartnoll R.G. \& Zarza-González E., 2013 - Morphological adaptations to anchialine environments in species of five shrimp families (Barbouria yanezi, Agostocaris bozanici, Procaris mexicana, Calliasmata nohochi and Typhlatya pearsei). Crustaceana, 86 (5): 578-593.

http://dx.doi.org/10.1163/15685403-00003197

Meland K. \& Willassen E., 2007 - The disunity of "Mysidacea" (Crustacea). Molecular Phylogenetics and Evolution, 44 (3): 1083-1104.

http://dx.doi.org/10.1016/j.ympev.2007.02.009

Mercado-Salas N.F., Morales-Vela B., Suárez-Morales E. \& Iliffe T.M., 2013 - Conservation status of the inland aquatic crustaceans in the Yucatan Peninsula, Mexico: shortcomings of a protection strategy. Aquatic Conservation: Marine and Freshwater Ecosystems, 23 (6): 939-951.

http://dx.doi.org/10.1002/aqc. 2350

Metzker M.L., 2010 - Sequencing technologies - the next generation. Nature Reviews Genetics, 11 (1): 31-46. http://dx.doi.org/10.1038/nrg2626

Meyer M., Stenzel U., Myles S., Prüfer K. \& Hofreiter M., 2007 - Targeted high-throughput sequencing of tagged nucleic acid samples. Nucleic Acids Research, 35 (15): e97. http://dx.doi.org/10.1093/nar/gkm566

Miller M.R., Dunham J.P., Amores A., Cresko W.A. \& Johnson E.A., 2007 - Rapid and cost-effective polymorphism identification and genotyping using restriction site associated DNA (RAD) marker. Genome Research, 17 (2): 240-248.

http://dx.doi.org/10.1101/gr.5681207 
Mock T. \& Kirkham A., 2012 - What can we learn from genomics approaches in marine ecology? From sequences to eco-systems biology. Marine Ecology, 33 (2): 131-148.

http://dx.doi.org/10.1111/j.1439-0485.2011.00479.x

Moore W.S., 1999 - The subterranean estuary: a reaction zone of ground water and sea water. Marine Chemistry, 65 (1-2): 111-125.

http://dx.doi.org/10.1016/S0304-4203(99)00014-6

Moritsch M.M., Pakes M.J. \& Lindberg D.R., $2014-$ How might sea level change affect arthropod biodiversity in anchialine caves: a comparison of Remipedia and Atyidae taxa (Arthropoda: Altocrustacea). Organisms Diversity \& Evolution, 14 (2): 225-235.

http://dx.doi.org/10.1007/s13127-014-0167-5

Myers N., Mittermeier R.A., Mittermeier C.G., Da Fonseca G.A. \& Kent J., 2000 - Biodiversity hotspots for conservation priorities. Nature, 403: 853-858.

http://dx.doi.org/10.1038/35002501

Mylroie J.E. \& Mylroie J.R., 2011 - Void development on carbonate coasts: creation of anchialine habitats. Hydrobiologia, 677 (1): 15-32. http://dx.doi.org/10.1007/s10750-010-0542-y

Namiotko T., Wouters K., Danielopol D.L. \& Humphreys W.F., 2004 - On the origin and evolution of a new anchialine stygobitic Microceratina species (Crustacea, Ostracoda) from Christmas Island (Indian Ocean). Journal of Micropalaeontology, 23: 49-59.

http://dx.doi.org/10.1144/jm.23.1.49

Neiber M.T., Hartke T.R., Stemme T., Bergmann A., Rust J., Iliffe T.M. \& Koenemann S., 2011 - Global biodiversity and phylogenetic evaluation of Remipedia (Crustacea). PLoS ONE, 6 (5): e19627.

http://dx.doi.org/10.1371/journal.pone.0019627

Neiber M.T., Hansen F.C., Iliffe T.M., Gonzalez B.C. \& Koenemann S., 2012 - Molecular taxonomy of Speleonectes fuchscockburni, a new pseudocryptic species of Remipedia (Crustacea) from an anchialine cave system on the Yucatán Peninsula, Quintana Roo,. Zootaxa, 3190: 31-46.

Neisch J., Pohlman J. \& Iliffe T.M., 2012 - The use of stable and radiocarbon isotopes as a method for delineating sources of organic material in anchialine systems. Natura Croatica, 21: 83-85.

Ng P., Guinot D. \& Iliffe T.M., 1996 - Revision of the anchialine varunine crabs of the genus Orcovita $\mathrm{Ng}$ \& Tomascik, 1994 (Crustacea: Decapoda: Brachyura: Grapsidae), with descriptions of four new species. The Raffles Bulletin of Zoology, 44 (1): 109-134.

Niemiller M.L., Graening G.O., Fenolio D.B., Godwin J.C., Cooley J.R., Pearson W.D., Fitzpatrick B.M. \& Near T.J., 2013 - Doomed before they are described? The need for conservation assessments of cryptic species complexes using an amblyopsid cavefish (Amblyopsidae: Typhlichthys) as a case study. Biodiversity and Conservation, 22 (8): 1799-1820. http://dx.doi.org/10.1007/s10531-013-0514-4

Oakley T.H., 2005 - Myodocopa (Crustacea: Ostracoda) as models for evolutionary studies of light and vision: multiple origins of bioluminescence and extreme sexual dimorphism. Hydrobiologia, 538: 179-192. http://dx.doi.org/10.1007/s10750-004-4961-5

Oakley T.H. \& Cunningham C.W., 2002 - Molecular phylogenetic evidence for the independent evolutionary origin of an arthropod compound eye. Proceedings of the National Academy of Sciences of the United States of America, 99: 1426-1430.

http://dx.doi.org/10.1073/pnas.032483599
Oakley T.H., Wolfe J.M., Lindgren A.R., Zaharoff A.K., 2013 - Phylotranscriptomics to bring the understudied into the fold: monophyletic ostracoda, fossil placement, and pancrustacean phylogeny. Molecular Biology and Evolution, 30: 215-233.

http://dx.doi.org/10.1093/molbev/mss216

Olesen J., Martinsen S.V., Ilifle T.M. \& Koenemann S., 2014 - Remipedia. In: Martin J., Olesen J. \& Høeg J. (Eds.), Atlas of Crustacean Larvae. John Hopkins University Press, Baltimore, Maryland, USA, p. 84-89.

Olesen J., Boesgaard T. \& Iliffe T.M., 2015 - The unique dorsal brood pouch of Thermosbaenacea (Crustacea, Malacostraca) and description of an advanced developmental stage of Tulumella unidens from the Yucatan Peninsula (Mexico), with a discussion of mouth part homologies to other Malacostraca. PLoS ONE, 10 (4): e0122463.

http://dx.doi.org/10.1371/journal.pone.0122463

Opsahl S.P. \& Chanton J.P., 2006 - Isotopic evidence for methane-based chemosynthesis in the Upper Floridan aquifer food web. Oecologia, 150 (1): 89-96.

http://dx.doi.org/10.1007/s00442-006-0492-2

O'Quin K.E., Yoshizawa M., Doshi P. \& Jeffery W.R., 2013 - Quantitative genetic analysis of retinal degeneration in the blind cavefish Astyanax mexicanus. PLoS ONE, 8 (2): e57281.

http://dx.doi.org/10.1371/journal.pone.0057281

Orsi W.D., Edgcomb V.P., Christman G.D. \& Biddle J.F., 2013 - Gene expression in the deep biosphere. Nature, 499: 205-208.

http://dx.doi.org/10.1038/nature12230

Page T.J., Humphreys W. \& Hughes J.M., 2008 - Shrimps down under: evolutionary relationships of subterranean crustaceans from Western Australia (Decapoda: Atyidae: Stygiocaris). PLoS ONE, 3 (2): e1618.

http://dx.doi.org/ 10.1371/journal.pone.0001618

Pakes M.J. \& Mejía-Ortíz L.M., 2014 - Chemosynthetic ectosymbiosis reported in the predatory anchialine cave endemic, Xibalbanus tulumensis (Yager, 1987) (Remipedia). Crustaceana, 87 (14): 1657-1667.

http://dx.doi.org/10.1163/15685403-00003376

Pakes M.J., Weis A.K. \& Mejia-Ortiz L., 2014 - Arthropods host intracellular chemosynthetic symbionts, too: cave study reveals an unusual form of symbiosis. Journal of Crustacean Biology, 34 (3): 334-341.

http://dx.doi.org/10.1163/1937240X-00002238

Pankey M.S., Minin V.N., Imholte G.C., Suchard M.A. \& Oakley T.H., 2014 - Predictable transcriptome evolution in the convergent and complex bioluminescent organs of squid. Proceedings of the National Academy of Sciences of the United States of America, 111 (44): E4736-E4742. http://dx.doi.org/10.1073/pnas.1416574111

Peck S.B. \& Finston T.L., 1993 - Galapagos islands troglobites: the questions of tropical troglobites, parapatric distributions with eyed-sister-species, and their origin by parapatric speciation. Mémoires de Biospéologie, 20: 19-37.

Peñalba J. V, Smith L.L., Tonione M.A, Sass C., Hykin S.M., Skipwith P.L., McGuire J.A, Bowie R.C.K. \& Moritz C., 2014 - Sequence capture using PCRgenerated probes: a cost-effective method of targeted high-throughput sequencing for nonmodel organisms. Molecular Ecology Resources, 14 (15): 1000-1010. http://dx.doi.org/ 10.1111/1755-0998.12249

Pesce G.L. \& Iliffe T.M., 2002 - New records of cave-dwelling mysids from the Bahamas and Mexico with description of Palaumysis bahamensis n. sp. (Crustacea: Mysidacea). Journal of Natural History, 36 (3): 265-278. http://dx.doi.org/10.1080/00222930010005033 
Peterson B.K., Weber J.N., Kay E.H., Fisher H.S. \& Hoekstra H.E., 2012 - Double digest RADseq: an inexpensive method for de novo SNP discovery and genotyping in model and non-model species. PLoS ONE, 7 (5): e37135.

http://dx.doi.org/10.1371/journal.pone.0037135

Petrescu I., 1995 - Cumaceans (Crustacea: Peracarida) from the South American coasts collected by the $R / V$ "Vema". Travaux du Muséum d'Histoire Naturelle Grigore Antipa, 35: 49-86.

Petrescu I., 2003 - Cumacea (Crustacea: Peracarida) from western tropical Atlantic. Travaux du Muséum National d'Histoire Naturelle Grigore Antipa, 45: 117-128.

Petrescu I. \& Iliffe T.M., 1992 - Contributions to the knowledge of the Cumacea species from the British Blue Holes, Andros Island (Bahamas). Travaux du Muséum National d'Histoire Naturelle Grigore Antipa, 32: 283-301.

Petrescu I. \& Iliffe T.M., 2009 - New species of Cumacea (Crustacea: Peracarida: Cumacea) from Bahamas. Travaux du Muséum National d'Histoire Naturelle Grigore Antipa, 52: 127-141.

Petrescu I., Iliffe T.M. \& Sarbu S., 1993 - Contributions to the knowledge of Cumacea (Crustacea) from the littoral waters of Jamaica Island, including the description of three new species (I). Travaux du Muséum National d'Histoire Naturelle Grigore Antipa, 33: 1-3.

Petrunina A.S., Neretina T.V., Mugue N.S., Kolbasov G.A., 2014 - Tantulocarida versus Thecostraca: inside or outside? First attempts to resolve phylogenetic position of Tantulocarida using gene sequences. Journal of Zoological Systematics and Evolutionary Research, 52 (2): 100-108.

http://dx.doi.org/10.1111/jzs.12045

Phillips M.J., Page T.J., De Bruyn M., Huey J.A., Humphreys W.F., Hughes J.M., Santos S.R., Schmidt D.J. \& Waters J.M., 2013 - The linking of plate tectonics and evolutionary divergence. Current Biology, 23 (14): R603-R605.

http://dx.doi.org/10.1016/j.cub.2013.06.001

Pohlman J.W., 2011 - The biogeochemistry of anchialine caves: progress and possibilities. Hydrobiologia, 677 (1): 33-51.

http://dx.doi.org/10.1007/s10750-011-0624-5

Pohlman J.W., Iliffe T.M. \& Cifuentes L.A., 1997 - A stable isotope study of organic cycling and the ecology of an anchialine cave ecosystem. Marine Ecology Progress Series, 155: 17-27.

http://dx.doi.org/10.3354/meps 155017

Poore G. \& Humphreys W., 1992 - First record of Thermosbaenacea (Crustacea) from the Southern Hemisphere: a new species from a cave in tropical Western Australia. Invertebrate Systematics, 6 (3): 719-725. http://dx.doi.org/10.1071/IT9920719

Por F., 2007 - Ophel: a groundwater biome based on chemoautotrophic resources. The global significance of the Ayyalon cave finds, Israel. Hydrobiologia, 592 (1): 1-10. http://dx.doi.org/10.1007/s10750-007-0795-2

Porter M.L., 2007 - Subterranean biogeography: what have we learned from molecular techniques. Journal of Cave and Karst Studies, 69 (1): 179-186.

Porter M.L., Meland K. \& Price W., 2007 - Global diversity of mysids (Crustacea-Mysida) in freshwater. Hydrobiologia, 595 (1): 213-218. http://dx.doi.org/10.1007/s10750-007-9016-2

Porter M.L., Engel A.S., Kane T.C. \& Kinkle B.K., 2009 - Productivity-diversity relationships from chemolithoautotrophically based sulfidic karst systems. International Journal of Speleology, 38 (1): 27-40. http://dx.doi.org/10.5038/1827-806X.38.1.4
Protas M.E., Hersey C., Kochanek D., Zhou Y., Wilkens H., Jeffery W.R., Zon L.I., Borowsky R. \& Tabin C.J., 2006 - Genetic analysis of cavefish reveals molecular convergence in the evolution of albinism. Nature Genetics, 38 (1): 107-111.

http://dx.doi.org/10.1038/ng1700

Protas M., Conrad M., Gross J.B., Tabin C. \& Borowsky R., 2007 - Regressive evolution in the Mexican cave tetra, Astyanax mexicanus. Current Biology, 17 (5): 452-454.

http://dx.doi.org/10.1016/j.cub.2007.01.051

Protas M.E., Trontelj P. \& Patel N.H.N., 2011 - Genetic basis of eye and pigment loss in the cave crustacean, Asellus aquaticus. Proceedings of the National Academy of Sciences of the United States of America, 108 (14): 5702-5707.

http://dx.doi.org/10.1073/pnas. 1013850108

Puillandre N., Macpherson E., Lambourdière J., Cruaud C., Boisselier-Dubayle M.C. \& Samadi S., 2011 Barcoding type specimens helps to identify synonyms and an unnamed new species in Eumunida Smith, 1883 (Decapoda:Eumunididae). Invertebrate Systematics, 25 (4): 322.

http://dx.doi.org/10.1071/IS11022

Qiu Q., Zhang G., Ma T., Qian W., Wang J., et al., 2012 The yak genome and adaptation to life at high altitude. Nature Genetics, 44 (8): 946-949.

http://dx.doi.org/10.1038/ng.2343

Ratnasingham S. \& Hebert P., 2007 - BOLD: the barcode of life data system (www.barcodinglife.org). Molecular Ecology Notes, 7: 355-364.

http://dx.doi.org/10.1111/j.1471-8286.2007.01678.x

Rehm P., Borner J., Meusemann K., von Reumont B.M., Simon S., Hadrys H., Misof B. \& Burmester T., 2011 - Dating the arthropod tree based on largescale transcriptome data. Molecular Phylogenetics and Evolution, 61 (3): 880-887.

http://dx.doi.org/10.1016/j.ympev.2011.09.003

Ribera I., Fresneda J., Bucur R., Izquierdo A., Vogler A.P., Salgado J.M. \& Cieslak A., 2010 - Ancient origin of a Western Mediterranean radiation of subterranean beetles. BMC Evolutionary Biology, 10: 29.

http://dx.doi.org/10.1186/1471-2148-10-29

Rohland N. \& Reich D., 2012 - Cost-effective, highthroughput DNA sequencing libraries for multiplexed target capture. Genome Research, 22 (5): 939-946.

http://dx.doi.org/10.1101/gr.128124.111

Rouch R., 1968 - Contribution à la connaissance des Harpacticides hypogés (Crustacés-Copépodes). Annales de Speleologie, 23: 9-167.

Rouch R., 1994 - Copepoda. In: Juberthie C. \& Decu V. (Eds.), Encyclopaedia Biospeologica, Tome I. Société Internationale de Biospéologie, Moulis, France, p. 105-111.

Russ A., Santos S.R. \& Muir C., 2010 - Genetic population structure of an anchialine shrimp, Metabetaeus lohena (Crustacea: Alpheidae), in the Hawaiian Islands. Revista de Biologia Tropical, 58 (1): 159-70.

Sahl J.W., Gary M.O., Harris J.K. \& Spear J.R., 2011 - A comparative molecular analysis of water-filled limestone sinkholes in north-eastern Mexico. Environmental Microbiology, 13 (1): 226-240.

http://dx.doi.org/10.1111/j.1462-2920.2010.02324.x

Santos S.R., 2006 - Patterns of genetic connectivity among anchialine habitats: a case study of the endemic Hawaiian shrimp Halocaridina rubra on the island of Hawaii. Molecular Ecology, 15 (10): 2699-2718. http://dx.doi.org/10.1111/j.1365-294X.2006.02965.x 
Sarbu S.M., Kane T.C. \& Kinkle B., 1996 - A chemoautotrophically based cave ecosystem. Science, 272: 1953-1955.

http://dx.doi.org/10.1126/science.272.5270.1953

Sathiamurthy E. \& Voris H.K., 2006 - Maps of Holocene sea level transgression and submerged lakes on the Sunda Shelf. The Natural History Journal of Chulalongkorn University, 2: 1-44.

Savolainen V., Cowan R.S., Vogler A.P., Roderick G.K. \& Lane R., 2005 - Towards writing the encyclopedia of life: an introduction to DNA barcoding. Philosophical Transactions of the Royal Society of London. Series B, Biological sciences, 360: 1805-1811.

http://dx.doi.org/10.1098/rstb.2005.1730

Seymour J., Humphreys W. \& Mitchell J., 2007 Stratification of the microbial community inhabiting an anchialine sinkhole. Aquatic Microbial Ecology, 50: 11-24. http://dx.doi.org/10.3354/ame01153

Shendure J. \& Ji H., 2008 - Next-generation DNA sequencing. Nature Biotechnology, 26 (10): 1135-1145. http://dx.doi.org/10.1038/nbt1486

Shokralla S., Gibson J.F., Nikbakht H., Janzen D.H., Hallwachs W. \& Hajibabaei M., 2014 - Next-generation DNA barcoding: using next-generation sequencing to enhance and accelerate DNA barcode capture from single specimens. Molecular Ecology Resources, 14: 892-901.

http://dx.doi.org/10.1111/1755-0998.12236

Sket B., 1985 - Why all cave animals do not look alike- a discussion on adaptive value of reduction processes. NSS Bulletin, 47 (2): 78-85.

Sket B., 1996 - The ecology of anchihaline caves. Trends in Ecology \& Evolution, 11 (5): 221-225. http://dx.doi.org/10.1016/0169-5347(96)20031-X

Sket B., 1999 - The nature of biodiversity in hypogean waters and how it is endangered. Biodiversity and Conservation, 8 (10): 1319-1338.

http://dx.doi.org/10.1023/A:1008916601121

Smith D.E., Harrison S., Firth C.R. \& Jordan J.T., 2011 - The early Holocene sea level rise. Quaternary Science Reviews, 30 (15-16): 1846-1860.

http://dx.doi.org/10.1016/j.quascirev.2011.04.019

Solis-Marín F.A. \& Laguarda-Figueras A., 2010 - A new species of starfish (Echinodermata: Asteroidea) from an anchialine cave in the Mexican Caribbean. Revista Mexicana de Biodiversidad, 81 (3): 663-668.

Spears T., Debry R.W., Abele L.G. \& Chodyla K., 2005 - Peracarid monophyly and interordinal phylogeny inferred from nuclear small-subunit ribosomal DNA sequences (Crustacea: Malacostraca: Peracarida). Proceedings of the Biological Society of Washington, 118 (1): 117-157.

http://dx.doi.org/10.2988/0006-324X(2005) 118 [117:PMAIPI]2.0.CO;2

Stegner M.E., Stemme T., Iliffe T.M., Richter S. \& Wirkner C.S., 2015 - The brain in three crustaceans from cavernous darkness. BMC Neuroscience, 16 (1): 19. http://dx.doi.org/10.1186/s12868-015-0138-6

Stemme T., Iliffe T.M., von Reumont B.M., Koenemann S., Harzsch S. \& Bicker G., 2013 - Serotoninimmunoreactive neurons in the ventral nerve cord of Remipedia (Crustacea): support for a sister group relationship of Remipedia and Hexapoda?. BMC Evolutionary Biology, 13 (1): 119.

http://dx.doi.org/10.1186/1471-2148-13-119

Stoch F., 1995 - The ecological and historical determinants of crustacean diversity in groundwaters, or: why are there so many species. Mémoires de Biospéologie, 22: 139-160.
Stock J.H., 1986 - The concept "anchialine" reconsidered. Stygologia, 2: 90-92.

Stull G.W., Moore M.J., Mandala V.S., Douglas N.A., Kates H.R., Qi X., Brockington S.F., Soltis P.S., Soltis D.E. \& Gitzendanner M.A., 2013 - A targeted enrichment strategy for massively parallel sequencing of angiosperm plastid genomes. Applications in Plant Sciences, 1 (2): 1200497.

http://dx.doi.org/10.3732/apps. 1200497

Suárez-Morales E. \& Iliffe T.M., 2005a - A new Exumella (Crustacea: Copepoda: Ridgewayiidae) from anchialine waters of the western Caribbean, with comments on regional biogeography. Bulletin of Marine Science, $\mathbf{7 7}$ (3): 409-423.

Suárez-Morales E. \& Iliffe T.M., 2005b - A new Stygonitocrella Petkouski (Copepoda: Harpacticoida) from a cave in Northern Mexico with comments on the taxonomy of the genus. Hydrobiologia, 544 (1): 215-228. http://dx.doi.org/10.1007/s10750-005-0621-7

Suárez-Morales E. \& Iliffe T.M., 2007 - A new genus of Ridgewayiidae (Copepoda: Calanoida) from a karstic cave of the western Caribbean. Journal of Crustacean Biology, 27 (2): 339-350.

http://dx.doi.org/10.1651/S-2720.1

Suárez-Morales E., Reid J.W., Fiers F. \& Iliffe T.M., 2004 - Historical biogeography and distribution of the freshwater cyclopine copepods (Copepoda, Cyclopoida, Cyclopinae) of the Yucatan Peninsula, Mexico. Journal of Biogeography, 31: 1051-1063.

http://dx.doi.org/10.1111/j.1365-2699.2004.01053.x

Suárez-Morales E., Ferrari F.D. \& Iliffe T.M., 2006 - A new epacteriscid copepod (Calanoida: Epacteriscidae) from the Yucatan Peninsula, Mexico, with comments on the biogeography of the family. Proceedings of the Biological Society of Washington, 119 (2): 222-238. http://dx.doi.org/10.2988/0006-324X(2006)119[222: ANECCE]2.0.CO;2

Suárez-Ulloa V., Fernández-Tajes J., Aguiar-Pulido V., Rivera-Casas C., González-Romero R., Ausio J., Méndez J., Dorado J. \& Eirín-López J.M., 2013a - The CHROMEVALOA database: a resource for the evaluation of Okadaic Acid contamination in the marine environment based on the chromatin-associated transcriptome of the mussel Mytilus galloprovincialis. Marine Drugs, 11 (3): 830-841.

http://dx.doi.org/10.3390/md11030830

Suárez-Ulloa V., Fernández-Tajes J., Manfrin C., Gerdol M., Venier P. \& Eirin-López J.M., 2013b - Bivalve omics: state of the art and potential applications for the biomonitoring of harmful marine compounds. Marine Drugs, 11: 4370-4389.

http://dx.doi.org/10.3390/md11114370

Tafe D.J. \& Greenwood J.G., 1996a - A new species of Schizotrema (Cumacea: Nannastacidae) from Moreton Bay, Queensland. Memoirs of the Queensland Museum, 39: 381-389.

Tafe D.J. \& Greenwood J.G., 1996b - The Bodotriidae (Crustacea: Cumacea) of Moreton Bay, Queensland. Memoirs of the Queensland Museum, 39: 391-482.

Tierney S.M., Cooper S.J.B., Saint K.M., Bertozzi T., Hyde J., Humphreys W.F. \& Austin A.D., 2015 - Opsin transcripts of predatory diving beetles: a comparison of surface and subterranean photic niches. Royal Society Open Science, 2 (1): 140386. http://dx.doi.org/10.1098/rsos.140386

Toonen R.J., Puritz J.B., Forsman Z.H., Whitney J.L., Fernandez-Silva I., Andrews K.R. \& Bird C.E., 2013 ezRAD: a simplified method for genomic genotyping in non-model organisms. PeerJ, 1: e203. http://dx.doi.org/10.7717/peerj.203 
Torales S.L., Rivarola M., Pomponio M.F., Gonzalez S., Acuña C. V, Fernández P., Lauenstein D.L., Verga A.R., Hopp H.E., Paniego N.B. \& Poltri S.N.M., 2013 - De novo assembly and characterization of leaf transcriptome for the development of functional molecular markers of the extremophile multipurpose tree species Prosopis alba. BMC Genomics, 14: 705.

http://dx.doi.org/10.1186/1471-2164-14-705

Triebel, E., 1941 - Zur Morphologie und Okologie der fossilen Ostracoden, mit Beschreibung eineger neuer Garrungen und Arten. Senckenbergiana, 23 (4-6): 294-400.

Trontelj P., Douady C.J., Fišer C., Gibert J., Gorički Š., Lefébure T., Sket B. \& Zakšek V., 2009 - A molecular test for cryptic diversity in ground water: how large are the ranges of macro-stygobionts? Freshwater Biology, 54 (4): 727-744.

http://dx.doi.org/10.1111/j.1365-2427.2007.01877.x

Turk, S., Sket B., \& Sarbu S.., 1996 - Comparison between some epigean and hypogean populations of Asellus aquaticus (Crustacea: Isopoda: Asellidae). Hydrobiologia, 337: 161-170. http://dx.doi.org/10.1007/BF00028517

Verovnik R., Sket B. \& Trontelj P., 2004-Phylogeography of subterranean and surface populations of water lice Asellus aquaticus (Crustacea: Isopoda). Molecular Ecology, 13: 1519-1532. http://dx.doi.org/10.1111/j.1365-294X.2004.02171.x

Villacorta C., Jaume D., Oromí P. \& Juan C., 2008 Under the volcano: phylogeography and evolution of the cave-dwelling Palmorchestia hypogaea (Amphipoda, Crustacea) at La Palma (Canary Islands). BMC Biology, 6: 7. http://dx.doi.org/10.1186/1741-7007-6-7

von Reumont B.M., Jenner R.A, Wills M.A, Dell'ampio E., Pass G., Ebersberger I., Meyer B., Koenemann S., Iliffe T.M., Stamatakis A., Niehuis O., Meusemann K. \& Misof B., 2012 - Pancrustacean phylogeny in the light of new phylogenomic data: support for Remipedia as the possible sister group of Hexapoda. Molecular Biology and Evolution, 29 (3): 1031-1045.

http://dx.doi.org/10.1093/molbev/msr270

von Reumont B.M., Blanke A., Richter S., Alvarez F., Bleidorn C. \& Jenner R.A, 2014 - The first venomous crustacean revealed by transcriptomics and functional morphology: remipede venom glands express a unique toxin cocktail dominated by enzymes and a neurotoxin. Molecular Biology and Evolution, 31 (1): 1-32.

http://dx.doi.org/10.1093/molbev/mst199

von Rintelen K., Page T.J., Cai Y., Roe K., Stelbrink B., Kuhajda B.R., Iliffe T.M., Hughes J. \& von Rintelen T., 2012 - Drawn to the dark side: a molecular phylogeny of freshwater shrimps (Crustacea: Decapoda: Caridea: Atyidae) reveals frequent cave invasions and challenges current taxonomic hypotheses. Molecular Phylogenetics and Evolution, $6 \mathbf{6 3}$ (1): 82-96.

http://dx.doi.org/10.1016/i.ympev.2011.12.015

Wägele J.W., Holland B., Dreyer H., Hackethal B., 2003 Searching factors causing implausible non-monophyly: ssu rDNA phylogeny of Isopoda Asellota (Crustacea: Peracarida) and faster evolution in marine than in freshwater habitats. Molecular Phylogenetics and Evolution, 28: 535-551.

http://dx.doi.org/10.1016/S1055-7903(03)00053-8

Walker-Smith G.K. \& Poore G.C.B., $2001-$ A phylogeny of the Leptostraca (Crustacea) with keys to families and genera. Memoirs of Museum Victoria, 58 (2): 383-410.

Wang Z., Gerstein M. \& Snyder M., 2009 - RNA-Seq: a revolutionary tool for transcriptomics. Nature Reviews Genetics, 10 (1): 57-63.

http://dx.doi.org/10.1038/nrg2484
Watanabe H., Kobayashi K., Kato Y., Oda S., Abe R., Tatarazako N. \& Iguchi T., 2008 - Transcriptome profiling in crustaceans as a tool for ecotoxicogenomics: Daphnia magna DNA microarray. Cell Biology and Toxicology, 24 (6): 641-647. http://dx.doi.org/10.1007/s10565-008-9108-4

Wiens J.J., Chippindale P.T. \& Hillis D.M., 2003 - When are phylogenetic analyses misled by convergence? A case study in Texas cave salamanders. Systematic Biology, 52 (4): 501-514.

http:/ /dx.doi.org/10.1080/10635150390218222

Wilcox T.P., García de León F.J., Hendrickson D.A. \& Hillis D.M., 2004 - Convergence among cave catfishes: long-branch attraction and a Bayesian relative rates test. Molecular Phylogenetics and Evolution, 31 (3): 1101-1113

http://dx.doi.org/10.1016/j.ympev.2003.11.006

Wilkens H., 1986 - The tempo of regressive evolution studies of the eye reduction in stygobiont fishes and decapod crustaceans of the gulf-coast and West Atlantic region. Stygologia, 2: 130-143.

Wilkens H., 2001 - Convergent adaptations to cave life in the Rhamdia laticauda catfish group (Pimelodidae, Teleostei). Environmental Biology of Fishes, 62 (1-3): 251-261.

http://dx.doi.org/10.1023/A:1011897805681

Williams J.E., Johnson J.E., Hendrickson D.A., Contreras-Balderas S., Williams J.D., NavarroMendoza M., McAllister D.E. \& Deacon J.E., 1989 Fishes of North America endangered, threatened, or of special concern: 1989. Fisheries, 14 (6): 2-20.

http://dx.doi.org/10.1577/15488446(1989)014<0002:FONAET >2.0.CO;2

Wilson E., 1985 - The biological diversity crisis. BioScience, 35 (11): 700-706.

http://dx.doi.org/10.2307/1310051

Wong J.M., Pérez-Moreno J.L., Chan T.Y., Frank T.M. \& Bracken-Grissom H.D., 2015 - Phylogenetic and transcriptomic analyses reveal the evolution of bioluminescence and light detection in marine deepsea shrimps of the family Oplophoridae (Crustacea: Decapoda). Molecular Phylogenetics and Evolution, 83: $278-292$.

http://dx.doi.org/10.1016/j.ympev.2014.11.013

Wu T., Ayres E., Li G., Bardgett R.D., Wall D.H. \& Garey J.R., 2009 - Molecular profiling of soil animal diversity in natural ecosystems: Incongruence of molecular and morphological results. Soil Biology and Biochemistry, 41 (4): 849-857.

http://dx.doi.org/10.1016/j.soilbio.2009.02.003

Shen X., Tian M., Yan B., Chu K., 2015-Phylomitogenomics of Malacostraca (Arthropoda: Crustacea). Acta Oceanologica Sinica, 34 (2): 84-92. http://dx.doi.org/10.1007/s13131-015-0583-1

Yager J., 1981 - Remipedia, a new class of Crustacea from a marine cave in the Bahamas. Journal of Crustacean Biology, 1: 328-333. http://dx.doi.org/10.2307/1547965

Yager J., 1987 - Speleonectes tulumensis, n. $s p$. (Crustacea, Remipedia) from 2 anchialine cenotes of the Yucatan Peninsula, Mexico. Stygologia, 3: 161-166.

Yager J., 1994 - Remipedia. In: Juberthie C. \& Decu V. (Eds.), Encyclopaedia Biospeologica, Tome I. Société Internationale de Biospéologie, Moulis, France, p. 87-90.

Yager J. \& Humphreys W., 1996 - Lasionectes exleyi, $s p$, nov., the first remipede crustacean recorded from Australia and the Indian Ocean, with a key to the world species. Invertebrate Systematics, 10 (1): 171-187. http://dx.doi.org/10.1071/IT9960171 
Zakšek V., Sket B. \& Trontelj P., 2007 - Phylogeny of the cave shrimp Troglocaris: Evidence of a young connection between Balkans and Caucasus. Molecular Phylogenetics and Evolution, 42 (1): 223-35.

http://dx.doi.org/10.1016/j.ympev.2006.07.009

Zakšek V., Sket B., Gottstein S., Franjević D. \& Trontelj P., 2009 - The limits of cryptic diversity in groundwater: phylogeography of the cave shrimp Troglocaris anophthalmus (Crustacea: Decapoda: Atyidae). Molecular Ecology, 18 (5): 931-946.

http://dx.doi.org/10.1111/j.1365-294X.2008.04061.x
Zeng V., Villanueva K.E., Ewen-Campen B.S., Alwes F., Browne W.E. \& Extavour C.G., 2011 - De novo assembly and characterization of a maternal and developmental transcriptome for the emerging model crustacean Parhyale hawaiensis. BMC Genomics, 12 (1): 581.

http://dx.doi.org/10.1186/1471-2164-12-581

Zhang W., Chen J., Yang Y., Tang Y., Shang J. \& Shen B., 2011 - A practical comparison of de novo genome assembly software tools for next-generation sequencing technologies. PLoS ONE, 6 (3): e17915.

http://dx.doi.org/10.1371/journal.pone.0017915 